\title{
Contribution of primary carbonaceous aerosol to cloud condensation nuclei: processes and uncertainties evaluated with a global aerosol microphysics model
}

\author{
J. R. Pierce ${ }^{1}$, K. Chen ${ }^{2}$, and P. J. Adams ${ }^{2,3}$ \\ ${ }^{1}$ Department of Chemical Engineering, Carnegie Mellon University, Pittsburgh, PA, USA \\ ${ }^{2}$ Department of Civil and Environmental Engineering, Carnegie Mellon University, Pittsburgh, PA, USA \\ ${ }^{3}$ Department of Engineering and Public Policy, Carnegie Mellon University, Pittsburgh, PA, USA
}

Received: 10 April 2007 - Published in Atmos. Chem. Phys. Discuss.: 4 June 2007

Revised: 3 September 2007 - Accepted: 18 October 2007 - Published: 19 October 2007

\begin{abstract}
This paper explores the impacts of primary carbonaceous aerosol on cloud condensation nuclei $(\mathrm{CCN})$ concentrations in a global climate model with size-resolved aerosol microphysics. Organic matter (OM) and elemental carbon (EC) from two emissions inventories were incorporated into a preexisting model with sulfate and seasalt aerosol. The addition of primary carbonaceous aerosol increased $\operatorname{CCN}(0.2 \%)$ concentrations by $65-90 \%$ in the globally averaged surface layer depending on the carbonaceous emissions inventory used. Sensitivity studies were performed to determine the relative importance of organic solubility/hygroscopicity in predicting CCN. In a sensitivity study where carbonaceous aerosol was assumed to be completely insoluble, concentrations of $\mathrm{CCN}(0.2 \%)$ still increased by $40-50 \%$ globally over the no carbonaceous simulation because primary carbonaceous emissions were able to become CCN via condensation of sulfuric acid. This shows that approximately half of the contribution of primary carbonaceous particles to $\mathrm{CCN}$ in our model comes from the addition of new particles (seeding effect) and half from the contribution of organic solute (solute effect). The solute effect tends to dominate more in areas where there is less inorganic aerosol than organic aerosol and the seeding effect tends to dominate in areas where there is more inorganic aerosol than organic aerosol. It was found that an accurate simulation of the number size distribution is necessary to predict the $\mathrm{CCN}$ concentration but assuming an average chemical composition will generally give a $\mathrm{CCN}$ concentration within a factor of 2 . If a "typical" size distribution is assumed for each species when calculating $\mathrm{CCN}$, such as is done in bulk aerosol models, the mean error relative to a simulation with size resolved microphysics is on the order of $35 \%$. Predicted values of carbonaceous aerosol mass
\end{abstract}

Correspondence to: J. R. Pierce

(jrpierce@andrew.cmu.edu) and aerosol number were compared to observations and the model showed average errors of a factor of 3 for carbonaceous mass and a factor of 4 for total aerosol number; however, errors in the accumulation mode concentrations were found to be lower in comparisons with European and marine observations.. The errors in $\mathrm{CN}$ and carbonaceous mass may be reduced by improving the emission size distributions of both primary sulfate and primary carbonaceous aerosol.

\section{Introduction}

Radiative forcing by aerosols is an important contributor to climate change (Forster et al., 2007). Compared to the positive (warming) radiative forcing caused by greenhouse gases, the magnitude of the negative (cooling) radiative forcing by aerosols remains uncertain. The largest uncertainty in aerosol forcing of climate is the indirect effect, wherein anthropogenic aerosols perturb the earth's climate by increasing cloud reflectance (Albrecht, 1989; Twomey, 1974). This occurs when anthropogenic activities increase the number of aerosol particles that serve as nuclei upon which cloud droplets form (cloud condensation nuclei or $\mathrm{CCN}$ ). The consequent increase in cloud droplet number concentrations (CDNC) leads to more reflective clouds that may have longer lifetimes (Albrecht, 1989; Twomey, 1974). The Intergovernmental Panel on Climate Change (IPCC) has estimated that the globally and annually averaged indirect aerosol radiative forcing lies between -0.3 and $-1.8 \mathrm{~W} \mathrm{~m}^{-2}$, with a median value of $-0.7 \mathrm{~W} \mathrm{~m}^{-2}$, as compared with $+2.5 \mathrm{~W} \mathrm{~m}^{-2} \mathrm{im}$ posed by changes in greenhouse gases (Forster et al., 2007). This estimate includes only the effect of aerosols on cloud albedo, neglecting changes in cloud cover. Uncertainty in the magnitude of aerosol forcing has plagued efforts to quantify the sensitivity of climate to anthropogenic perturbations

Published by Copernicus Publications on behalf of the European Geosciences Union. 
(Andreae et al., 2005; Schwartz, 2004). Clearly it is necessary to improve our estimates of the indirect effect.

To estimate the indirect radiative forcing, it is essential to understand the activation of aerosol particles to form cloud droplets under supersaturated conditions. Whether or not a particle activates depends on the ambient supersaturation as well as particle size and composition. Therefore, a physically based model of the indirect effect should predict the number size distribution of aerosols and the chemical composition of each size range to predict the number of $\mathrm{CCN}$ for any supersaturation. Knowledge of aerosol mixing state is also essential for correct prediction of $\mathrm{CCN}$ activation behavior.

Carbonaceous aerosols, mainly produced from fossil fuel and biomass combustion, are composed of two classes of material: elemental carbon (EC) and organic matter (OM). Elemental carbon is emitted directly from primary sources. OM, in contrast, is both emitted as particulates (primary OM) and also condensed in the atmosphere from semi-volatile oxidation products of volatile organic compounds. The latter is referred to as secondary organic aerosol (SOA).

Carbonaceous aerosols are considered to be a strong contributor to the indirect effect (Novakov and Penner, 1993). Lohmann et al. (2000) predict an indirect effect of $-0.9 \mathrm{~W} \mathrm{~m}^{-2}$ from anthropogenic carbonaceous aerosol alone compared to $-0.4 \mathrm{~W} \mathrm{~m}^{-2}$ from sulfate aerosol alone, and $-1.1 \mathrm{~W} \mathrm{~m}^{-2}$ from an internal mixture of the two. Chuang et al. (2002) estimate a total cloud albedo forcing of $-1.85 \mathrm{~W} \mathrm{~m}^{-2}$, with $-0.30 \mathrm{~W} \mathrm{~m}^{-2}$ and $-1.51 \mathrm{~W} \mathrm{~m}^{-2}$ from sulfate and carbonaceous aerosols alone, respectively. Hitzenberger et al. (1999) observed, in rural Europe sites, that carbonaceous material contributed up to $67 \%$ of total aerosol mass in $\mathrm{CCN}$ size range; in urban areas, the contribution of $\mathrm{OM}$ to the total mass concentration in this size range was $48 \%$. Based on these studies, it seems likely that carbonaceous aerosol plays an important role in the tropospheric CCN budget. Therefore, it is essential to understand the global distribution of mass and number concentrations and size distribution of carbonaceous aerosols.

A number of previous modeling studies using bulk aerosol models have been performed to estimate the global distribution of carbonaceous aerosols (Chung and Seinfeld, 2002; Cooke et al., 1999; Cooke and Wilson, 1996; Liousse et al., 1996; Lohmann et al., 2000; Penner et al., 1998; Reddy and Boucher, 2004). However, these studies must make assumptions about the aerosol size distribution or use empirical relations to predict CDNC from their predicted aerosol mass. Besides the uncertainties inherent in the empirical approach, it has the disadvantage of concealing the physical processes that control CCN concentrations, introducing the difficulty of testing the sensitivity of model behavior to uncertainties or changes in specific microphysical processes such as nucleation.

The most fundamental, albeit computationally intensive, method predicting aerosol size distributions results is solving aerosol microphysics explicitly using the aerosol gen- eral dynamic equation (Seinfeld and Pandis, 1998), which governs how the aerosol size distribution evolves as a result of the microphysical processes of nucleation, condensation, and coagulation. Numerical algorithms for treating aerosol microphysics can be broadly categorized as modal, moment-based, or sectional. To our knowledge, momentbased approaches have not been implemented into global models for the purposes of predicting CCN concentrations although regional-scale applications have been demonstrated (Yu et al., 2003). Modal algorithms that represent the aerosol size distribution as the sum of several lognormal distributions, each characterized by a number concentration, median diameter, and geometric standard deviation, have been developed by Herzog et al. (2004), Jung et al. (2004) and Vignati et al. (2004) and implemented in Easter et al. (2004), Ghan et al. (2001), Stier et al. (2005) and Wilson et al. (2001) in global models. Except for Jung et al. (2004), the versions of the modal approach cited here have prescribed constant values to the geometric standard deviations such that only two of the three lognormal parameters are predicted variables. Zhang et al. (1999) demonstrated that allowing the geometric standard deviation to vary results in greater accuracy under some conditions. An advantage of the modal approach is its computational efficiency compared to sectional algorithms. This efficiency permits an explicit treatment of aerosol mixing (Stier et al., 2005; Vignati et al., 2004; Wilson et al., 2001). The modal representation has an inherent disadvantage, however, in treating processes such as activation and cloud chemistry that create discontinuities in the size distribution, at least on a local basis. For example, in box model simulations with cloud processing of aerosol particles, Zhang et al. (2002) found normalized absolute errors of $6 \%$ to $34 \%$ in the number of activated particles predicted by the modal approach with either two or three predicted variables.

Single-moment aerosol sectional algorithms have been applied to the problem of global aerosol microphysics (Gong et al., 2003; Rodriguez and Dabdub, 2004). In the singlemoment sectional approach, the masses of each aerosol species in each size section are calculated while the number of aerosol particles in each bin is inferred. Because the aerosol microphysical equations are formulated in terms of aerosol mass, they generally do not conserve aerosol number concentrations during the condensation process. Although the treatment of condensation may be formulated to conserve aerosol number in these algorithms, such a formulation induces unwanted numerical diffusion in the aerosol size distribution (Adams and Seinfeld, 2002). Note that we do not include in this category numerous size-resolved global models of predominantly coarse mode aerosols such as sea-salt and mineral dust (e.g. Tegen and Lacis, 1996), which are not microphysical models because they do not solve the aerosol condensation and coagulation equations. In such models, the size resolution accounts for important size-dependent optical properties and depositional behavior while condensation and coagulation processes generally have a negligible impact on 
the coarse mode.

Two-moment sectional approaches (Tzivion et al., 1989; Tzivion et al., 1987) and the similar "moving-center" approach (Jacobson, 2002) represent a flexible treatment of aerosol microphysics that reduce the effect of numerical diffusion. In these approaches, the mass (of each aerosol component) and number concentrations are tracked as independent parameters for each size section, thereby avoiding the limitations of other approaches discussed above. Although they are computationally intensive, several applications to tropospheric aerosol microphysics in threedimensional, global-scale models have been demonstrated (Adams and Seinfeld, 2002; Jacobson, 2001; Pierce and Adams, 2006; Spracklen et al., 2006; Spracklen et al., 2005a, 2005b).

We have simplified the effects of primary carbonaceous particles on $\mathrm{CCN}$ concentrations by grouping them into two different pathways. The first pathway, which we refer to as the "carbonaceous seeding effect", occurs when carbonaceous emissions increase the number of particles in the atmosphere and potentially increases the number of CCN. The increase in $\mathrm{CCN}$ due to carbonaceous seeding can occur regardless of the size and solubility of the primary carbonaceous particles if more hygroscopic gases such as sulfuric acid condense onto these particles (Adams and Seinfeld, 2003; Pierce and Adams, 2006). The second pathway for $\mathrm{CCN}$ increase from carbonaceous particles is the contribution of $\mathrm{OM}$ to the number of soluble molecules within atmospheric particles, which we refer to as the "organic solute effect". The implications of the competition between these two pathways are as follows. To the extent that the carbonaceous seeding effect is important, the number and sizes of primary emissions must be understood to accurately predict CCN. Subsequently, if the organic solute is important, understanding OM chemistry/composition becomes important in the prediction of CCN. It is not obvious a priori which one of these two effects contributes more to $\mathrm{CCN}$ and will be explored in this paper. The two pathways explored here do not include the effects of organics on particle surface tension and the increased organic mass that SOA may partition into, both of which affect CCN.

This paper documents the incorporation of carbonaceous aerosols in the highly size-resolved TwO-Moment Aerosol Sectional (TOMAS) microphysics model (Adams and Seinfeld, 2002). We estimate the contribution of primary carbonaceous aerosol to $\mathrm{CCN}$ formation on a global scale. Since most of the carbonaceous aerosol number is emitted in the ultrafine size range, we determine how ultrafine carbonaceous particles grow to be $\mathrm{CCN}$ by coagulation and condensation processes. Although this model does not yet take into account mineral dust, the simulation has included almost all aerosol number and $\mathrm{CCN}$ concentrations because mineral dust is mostly in coarse mode and does not contribute much to $\mathrm{CCN}$ concentrations. We perform sensitivity runs to test model assumptions regarding carbonaceous aerosol solubil- ity and mixing state. Using these sensitivity runs we determine the relative contributions to the $\mathrm{CCN}$ concentrations from the addition of new particles (carbonaceous seeding effect) verses the addition of organic solute (organic solute effect).

Section 2 of this paper describes the essential elements of the model we developed to simulate the global distributions of carbonaceous aerosol. Section 3 is the main results and discussion including carbonaceous budgets, comparisons of carbonaceous mass and aerosol number to observations and the contribution of carbonaceous aerosol to CCN. Finally, Sect. 4 presents the main conclusions from this work.

\section{Model description}

\subsection{Overview}

We use the TwO-Moment Aerosol Sectional (TOMAS) microphysics model developed by Adams and Seinfeld (2002), which adapted cloud microphysics algorithms from Stevens et al. (1996), Tzivion et al. (1987) and Tzivion et al. (1989) to aerosol processes. TOMAS tracks two independent moments, number and mass, of the aerosol size distribution for each size bin or category.

The TOMAS microphysics model is implemented in the Goddard Institute for Space Studies (GISS) II-prime GCM. In the GISS GCM II-prime, the time step for tracer processes is one hour. It has a horizontal resolution of 4 degrees latitude by 5 degrees longitude and 9 vertical layers from the surface to the model top at $10 \mathrm{mb}$ (Hansen et al., 1983). It is not certain what model resolution is necessary to predict accurately CCN concentrations. Sea-surface temperatures are specified as the mean values from 1979-1993. A fourth-order scheme for momentum advection is included in the GCM. Chemical tracers, heat, and moisture are advected every hour using a quadratic upstream scheme (Prather, 1986). In the GCM, TOMAS is configured to include 30 size bins defined in terms of dry particle mass and spanning a size range roughly corresponding to particle diameters of $10 \mathrm{~nm}$ to $10 \mu \mathrm{m}$. For each size bin, the model tracks eight quantities: sulfate mass, sea-salt mass, mass of pure EC, mass of mixed EC, mass of hydrophobic OM, mass of hydrophilic OM, mass of water and also the number of aerosol particles in that bin. Besides these size-resolved aerosol tracers, the model tracks four bulk gas-phase species: $\mathrm{H}_{2} \mathrm{O}_{2}, \mathrm{SO}_{2}$, DMS and $\mathrm{H}_{2} \mathrm{SO}_{4}$. One bulk aerosol species, MSA, is also predicted. Therefore, a total of 245 ( 30 bins $\times 8$ tracers per bin +5 bulk species) tracers are tracked online in the GISS GCM II-prime. We use the binary nucleation scheme detailed in Adams and Seinfeld (2002), in which new particles are generated when sulfuric acid concentrations exceed threshold values given in Wexler et al. (1994).

The size-resolved dry deposition of sulfate aerosols, seasalt, EC and OM is calculated as in work of Adams and Seinfeld (2002), which is based on a resistance-in-series 
parameterization (Wesely and Hicks, 1977). The scheme calculates quasi-laminar resistances as a function of particle size, accounts for gravitational settling of aerosols, and assumes there is no surface resistance for aerosols.

Wet deposition consists of in-cloud scavenging and belowcloud scavenging. In-cloud scavenging removes particles that activate to form cloud drops if those drops precipitate. In large-scale and convective clouds, particles that activate at $0.2 \%$ and $1.0 \%$ supersaturation, respectively, are considered to nucleate into cloud droplets. The critical supersaturation for activation of each size section is found using modified Köhler theory (Hanel, 1976; Laaksonen et al., 1998; Raymond and Pandis, 2003; Seinfeld and Pandis, 1998). This will be discussed more in Sect. 2.3. In these simulations, we neglect interstitial scavenging in clouds. The fraction of aerosol that activates and is subject to wet removal accounts for essentially all the aerosol mass. Below-cloud scavenging removes particles of all sizes colliding with falling raindrops. A first-order removal scheme (Koch et al., 1999) is applied to aerosol below precipitating clouds to simulate below-cloud scavenging with a size-dependent removal constant (Adams and Seinfeld, 2002).

In all simulations, externally mixed or pure populations are treated as externally mixed only for purposes of cloud processes such as activation and wet deposition. During microphysics, all aerosols are treated as internally mixed. While this is a limitation of the present work, it does allow us to explore the sensitivity of $\mathrm{CCN}$ and wet deposition to aerosol chemical composition without the computational expense of a multi-population microphysics model.

\subsection{Emissions}

In this work, we adopt an earlier size-resolved sulfur cycle model by Adams and Seinfeld (2002). The anthropogenic sulfur emissions are from the GEIA inventory (Benkovitz et al., 1996). As discussed in Adams and Seinfeld (2002), three percent of the total anthropogenic sulfur is emitted as particulate sulfate, mostly ultrafine, to represent plume processing of power plant emissions. This work uses the sea-salt emissions parameterization given in Clarke et al. (2006) and applied to the model as in Pierce and Adams (2006). Clarke et al. (2006) conducted a coastal field campaign to find the sea-salt number flux and fit the size distribution of the emissions flux to polynomials spanning dry diameters of $10 \mathrm{~nm}$ to $8 \mu \mathrm{m}$.

Anthropogenic primary carbonaceous aerosol emissions result mainly from biomass burning and fossil fuel combustion. We use two different carbonaceous emissions inventories in the model. The first inventory is that used by the IPCC Third Assessment Report (IPCC, 2001). In that report, the fossil fuel EC emissions inventory is based on the work of Penner et al. (1993), and other emission inventories including biomass EC, biomass OM, fossil fuel OM are based on the work of Liousse et al. (1996). The biomass burning
$\mathrm{EC}$ and $\mathrm{OM}$ in this work uses monthly averaged emissions whereas the fossil fuel EC and OM are annually averaged. The base year for these emissions is 2000 (IPCC, 2001). The second inventory is that of Bond et al. (2004). The base year of the Bond et al. (2004) emissions is 1996 for fossil fuel and biomass burning and the open burning is based on fire counts during 1999-2000.To convert the organic carbon (OC) mass presented in Bond et al. (2004) to OM we assume an OM:OC ratio of 1.8 (El-Zanan et al., 2005; Yu et al., 2005; Zhang et al., 2005). The assumption of a single value for this ratio is a source of uncertainty. We add seasonality to the Bond et al. (2004) open burning emissions by scaling the emissions by the fractions of the grid cells that are on fire as used by Liousse et al. (1996), while keeping their total annual emissions from open burning constant. In grid cells where Bond et al. (2004) has open burning emissions and Liousse et al. (1996) does not specify fire fraction, the open burning emissions are constant from month to month.

As pointed out by Adams and Seinfeld (2003), emissions of primary particles have a disproportionate impact per unit mass on global CCN concentrations via a "seeding" effect. Carbonaceous emissions inventories have not traditionally compiled size distribution data. Stanier et al. (2004), estimated that the size distribution of primary aerosols emitted by vehicles in a highway tunnel during the Pittsburgh Air Quality Study was approximately lognormal with a mass median diameter of $100 \mathrm{~nm}$ and a geometric standard deviation of 1.8. By measuring aerosol size distributions near a road, Janhall et al. (2004) found the number median diameter of particle emissions to be $25 \mathrm{~nm}$ with a standard deviation of 2. Similar to both these results, this work assumes the size distributions of primary emissions fit a lognormal size distribution function with mass median diameter of $100 \mathrm{~nm}$ and a geometric standard deviation of 2 for both EC and OM. The use of a single size distribution to represent emissions of all carbonaceous species will add uncertainty to our predictions because the size of particles emitted from open burning and internal combustion differ (Rissler et al., 2004, 2006). Also, uncertainty arises due to use of near-source size distributions as opposed to the size distribution of particles well mixed within the grid-cell. In a later section, we will compare the number concentrations predicted by our model against observations to evaluate this assumption.

\subsection{Carbonaceous aerosol hydroscopicity, chemistry, and mixing state}

This model divides carbonaceous aerosols into four categories: pure EC, mixed EC, hydrophobic OM and hydrophilic OM. For purposes of activation calculations and nucleation scavenging, we consider two populations of aerosols. The first population consists solely of externally mixed or pure EC while the second population is an internal mixture of all remaining carbonaceous species plus seasalt and sulfate. We will refer to these as the "pure EC" and 
Table 1. Overview of simulations.

\begin{tabular}{lccccc}
\hline Name & $\begin{array}{c}\text { Carbonaceous } \\
\text { Emissions Reference }\end{array}$ & $\begin{array}{c}\text { OM Emissions } \\
\text { Rate (Tg/yr) }\end{array}$ & $\begin{array}{c}\text { EC Emissions } \\
\text { Rate (Tg/yr) }\end{array}$ & $\begin{array}{c}\text { OM } \\
\text { Soluble }\end{array}$ & $\begin{array}{c}\text { Carbonaceous } \\
\text { Mixing State }\end{array}$ \\
\hline NOCARB & None & 0 & 0 & NA & NA \\
BBASE & Bond et al. (2004) & 61 & 8 & Yes & Internal \\
BCINS & Bond et al. (2004) & 61 & 8 & No & Internal \\
BCEXT & Bond et al. (2004) & 61 & 8 & Yes & External \\
IBASE & IPCC (2001) & 81.5 & 12.4 & Yes & Internal \\
ICINS & IPCC (2001) & 81.5 & 12.4 & No & Internal \\
ICEXT & IPCC (2001) & 81.5 & 12.4 & Yes & External \\
\hline
\end{tabular}

"mixed" populations, respectively. As pure EC is insoluble, it is not able to activate to CCN. We assume that the mixed $\mathrm{EC}$ is itself insoluble but may activate because it is mixed with soluble species. Hydrophobic and hydrophilic OM are assumed to be insoluble and completely soluble, respectively. While representing the entire spectrum of OM species with only two model tracers is a simplification, the mixing rule of the hygroscopicity parameter $(\kappa)$ in Petters and Kreidenweis (2007) suggests that any complex organic mixture can be represented by a correctly weighted mixture of a highly hydrophilic group and a highly hydrophobic group (high/low $\kappa)$.

Hydrophobic and hydrophilic OM each represent a mixture of organic components with varying activation behaviors. We assume that hydrophilic OM has a critical dry diameter of activation of $140 \mathrm{~nm}$ at $0.2 \%$ supersaturation (the corresponding value of the $\kappa$ parameter discussed in Petters and Kreidenweis, 2007 is 0.12 ), a value representative of more hygroscopic organic compounds. The hydrophobic OM was assumed to be insoluble $(\kappa=0)$. Model simulations that assumed a low solubility $\left(0.01 \mathrm{~g}\right.$ per $\left.100 \mathrm{~cm}^{3} \mathrm{H}_{2} \mathrm{O}\right)$ as opposed to no solubility were performed, and the resulting $\mathrm{CCN}(0.2 \%)$ concentrations differed by $<1 \%$. The assumed density of hydrophilic OM is $1.4 \mathrm{~g} \mathrm{~cm}^{-3}$ and hydrophobic $\mathrm{OM}$ is $1.8 \mathrm{~g} \mathrm{~cm}^{-3}$. These values are within the range used in (Kinne et al., 2003) and the CCN predictions do not depend strongly on the assumed density (it depends more strongly on the moles of solute).

For our mixed aerosol population, we use modified Köhler theory to calculate the number of $\mathrm{CCN}$ in the model along with the number of active particles in clouds for wet deposition (Hanel, 1976; Laaksonen et al., 1998; Raymond and Pandis, 2003; Seinfeld and Pandis, 1998). This allows for the calculation of the activation diameter of particles containing various soluble and insoluble (EC and hydrophobic OM) components. The hydrophilic OM contributes the appropriate number of solute molecules per OM mass to give an activation diameter of $140 \mathrm{~nm}$ at $0.2 \%$ supersaturation for a pure hydrophilic OM particle. Sulfate is assumed to be ammonium bisulfate that completely dissociates (van't Hoff factor of 3) and sea-salt is assumed to be sodium chloride with a van't Hoff factor of 2. Hydrophobic OM and all EC are assumed to be an insoluble core. In this treatment, we ignore changes in surface tension due to the contribution of surfactants by the organic aerosol.

In this work, $80 \%$ of EC is emitted into the pure EC population while the other $20 \%$ is added to the mixed EC population; half of total primary OM emitted is assumed to be hydrophobic and the other half hydrophilic following Cooke et al. (1999). In the atmosphere, hydrophobic carbonaceous aerosols become hydrophilic by several means: coating by condensation of soluble species such as sulfate or secondary organic aerosols (SOA) (Park et al., 2005; Riemer et al., 2004; Weingartner et al., 1997), coagulation with hydrophilic aerosols (FassiFihri et al., 1997; Riemer et al., 2004; Strom et al., 1992), or by heterogeneous chemistry (Eliason et al., 2003, 2004; FassiFihri et al., 1997; Moise and Rudich, 2002; Park et al., 2005; Riemer et al., 2004; Strom et al., 1992; Weingartner et al., 1997; Zuberi et al., 2005). The time scale for converting hydrophobic carbonaceous aerosols into hydrophilic aerosols is one of the main factors that affects the wet deposition lifetime of aerosols and thus has significant effect on aerosol mass and number concentrations (Cooke and Wilson, 1996; Park et al., 2005). However, this time scale remains uncertain and previous studies generally assume somewhat arbitrary time scales. In previous studies, the assumed time scale has been as low as 1.15 days (Cooke et al., 1999) and as high as 1.8 days (Koch et al., 1999). In this work we assume hydrophobic aerosols convert to hydrophilic aerosols with a lifetime of 1.5 days. This timescale is shorter than the mean lifetime of particles in the atmosphere, so uncertainties in the aging timescale should have only a modest affect on the carbonaceous burden.

In this work we do not consider SOA. Representation of SOA in global aerosol models is a developing field and current global estimates of SOA have high uncertainty (Kanakidou et al., 2005); future work should consider SOA formation as it may contribute largely to the carbonaceous mass (Volkamer et al., 2006). It should be noted that the model does underpredict OM mass compared to observations 
Table 2. Carbonaceous budget information.

\begin{tabular}{lcccc}
\hline \multirow{2}{*}{ Reference } & \multicolumn{2}{c}{ EC } & \multicolumn{2}{c}{ OC } \\
& Burden (Tg) & Lifetime (days) & Burden (Tg) & Lifetime (days) \\
\hline BBASE & 0.19 & 8.48 & 0.80 & 4.80 \\
IBASE & 0.29 & 8.44 & 1.22 & 5.47 \\
Chung and Seinfeld (2002) & 0.22 & 6.4 & 1.2 & 5.3 \\
Cooke and Wilson (1996) & 0.28 & 7.85 & NA & NA \\
Liouse et al. (1996) & 0.13 & 3.9 & NA & NA \\
Cooke et al. (1999) & 0.073 & 5.29 & 0.11 & 4.54 \\
Koch (2001) & 0.15 & 4.4 & 0.95 & 3.86 \\
\hline
\end{tabular}

(Sect. 3.2). The omission of SOA is likely to account for some of this underprediction and thus the contribution of carbonaceous aerosol to $\mathrm{CCN}$ may be underestimated.

\subsection{Overview of simulations}

The various base case and sensitivity simulations discussed in this paper are summarized in Table 1. All simulations are spun up for six months followed by one year of simulation time. The NOCARB model simulation contains no carbonaceous aerosol and is the same as the CLRK simulation in Pierce and Adams (2006) with the exception that the aerosol activation cutoff diameters in NOCARB depend on the composition (ratio of sulfate and sea-salt) according to Köhler theory, where in CLRK the cutoff diameters were constant. This does not greatly affect the aerosol burdens and CCN predictions because both sulfate and sea-salt are similarly hygroscopic. BBASE and IBASE are the base case simulations for the Bond et al. (2004) and IPCC (2001) emissions, respectively. In these runs, the assumptions about carbonaceous solubility and aerosol mixing state are as described in the previous sections. In the BCINS and ICINS simulations, the mixing assumptions of the base case runs are the same, but all carbonaceous aerosol is treated as insoluble. These simulations give a lower bound of CCN production with the current emissions in this model due to uncertainty in the solubility of $\mathrm{OM}$ and also isolate the effect of carbonaceous seeding on CCN concentrations. The BCEXT and ICEXT simulations use the solubility assumptions of the base cases, but treat four populations as externally mixed during cloud processes: 1) sulfate, 2) sea-salt, 3) hydrophobic OM, hydrophilic OM and mixed EC and 4) pure EC. The internally mixed carbonaceous are lumped together to simulate carbonaceous sources that have a mixture of OM and EC. These simulations explore how the mixing state of carbonaceous aerosol with inorganic salts affects $\mathrm{CCN}$ concentrations. In the BCEXT and ICEXT simulations, all species are treated as internally mixed during aerosol processes such as coagulation, condensation and dry deposition, but externally mixed during cloud processes such as wet deposition and aqueous oxidation. This assumption does not appreciably alter micro- physical growth rates because condensation and coagulation rates depend primarily on aerosol size, not composition. A second-order effect is the effect of aerosol mixing state on water uptake and, therefore, on condensation and coagulation growth rates. This is a limitation of the current study; nevertheless, these sensitivity simulations provide insight about the importance of mixing state on cloud processes.

\section{Results and discussion}

In this section we will evaluate the model against direct measurements of carbonaceous mass and aerosol number concentrations as well as measurements of the aerosol size distribution. This will be followed by a discussion of how primary carbonaceous aerosol affects $\mathrm{CCN}$ concentrations as well as an exploration of the importance of aerosol size and composition in predicting CCN. The model is currently unevaluated against satellite and AERONET derived aerosol optical depth (AOD) and angstrom coefficient measurements. This evaluation is being performed on an improved version of the model that also includes dust aerosol (Lee et al., 2007a $\mathrm{a}^{1}$; Lee et al., $2007 b^{2}$ ).

\subsection{Aerosol budgets}

The burden and lifetime of EC and OM for the two base case runs and various previous publications are given in Table 2. The lifetimes of OM differ between the BBASE and IBASE runs due to the emissions in different regions, whereas the lifetime of EC is the same between the two simulations. The average global burdens for both components are different between the two simulations due to different emissions rates. The burden and lifetime values for the BBASE and IBASE simulations are generally within the range of values

\footnotetext{
${ }^{1}$ Lee, Y., Chen, K., and Adams, P. J.: Development of a global model of mineral dust aerosol microphysics, in preparation, 2007a.

${ }^{2}$ Lee, Y., Chen, K., and Adams, P. J.: Evaluation of a global aerosol microphysics model against AERONET, MODIS, and MISR measurements of optical depth, in preparation, 2007b.
} 
Table 3. Inorganic budget information.

\begin{tabular}{lcccc}
\hline \multirow{2}{*}{ Simulation } & \multicolumn{2}{c}{ Sulfate } & \multicolumn{2}{c}{ Sea-salt } \\
& Burden (Tg) & Lifetime (days) & Burden (Tg) & Lifetime (days) \\
\hline NOCARB & 0.754 & 6.12 & 15.82 & 0.801 \\
BBASE & 0.750 & 6.08 & 15.83 & 0.801 \\
IBASE & 0.745 & 6.05 & 15.83 & 0.801 \\
\hline
\end{tabular}
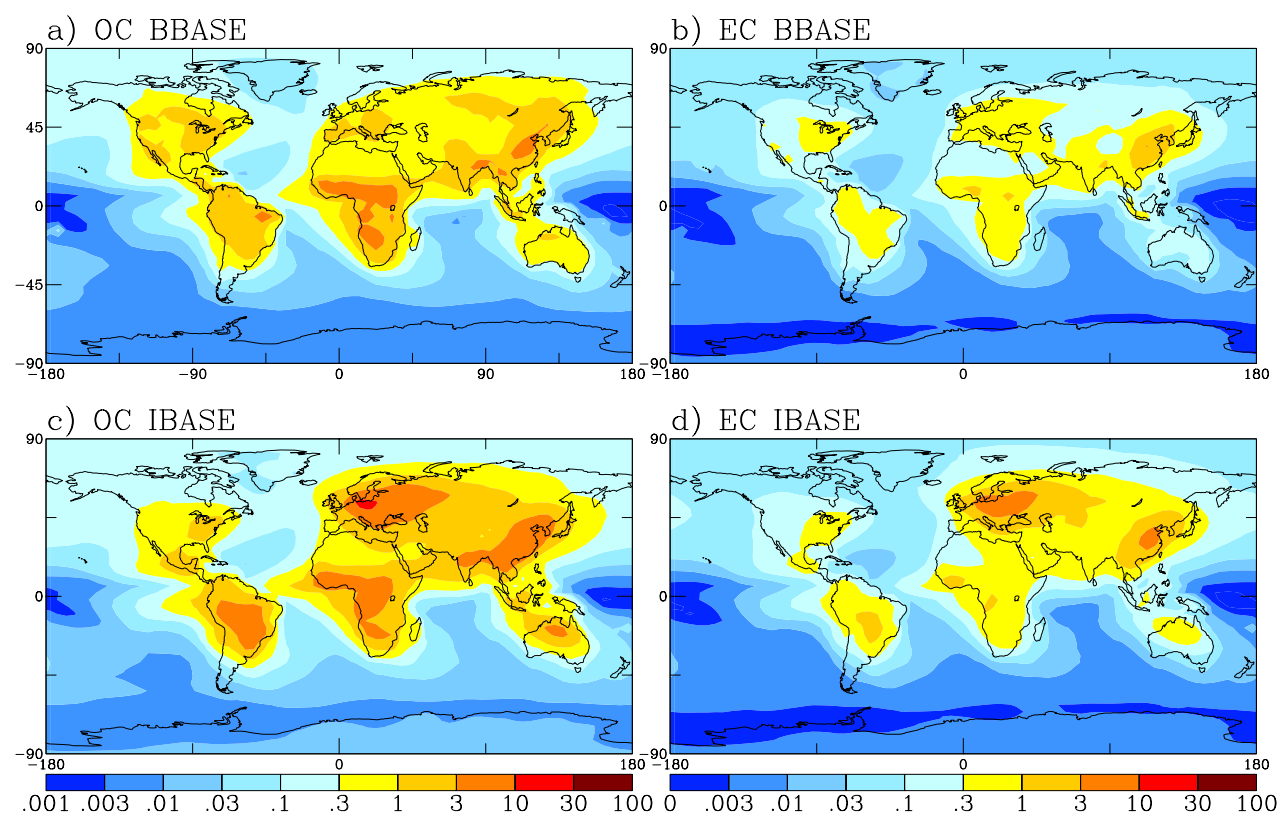

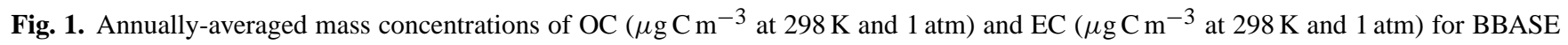
and IBASE.

presented in the previous work with the EC lifetime being somewhat longer in our model.

Table 3 shows the burden and lifetime of inorganic species in the model without carbonaceous aerosol (NOCARB) and with carbonaceous aerosol (BBASE and IBASE). The sulfate aerosol shows a very minor decrease in burden and lifetime when the carbonaceous aerosol is added. This is likely either due to condensation of sulfate onto the carbonaceous particles, which are emitted at a slightly larger size than primary sulfate particles, or a reduction of nucleation in favor of condensation of existing particles. Both of these shift sulfate mass to larger sizes where they may be removed quickly. The sea-salt aerosol burden and lifetime does not show a change between the simulations because most of the mass is already at large sizes.

\subsection{Carbonaceous mass}

Figure 1 shows the annual-average OC and EC mass concentrations for the model surface layer of the BBASE and
IBASE simulations. Note that we present our OC concentration as $\mu \mathrm{g} \mathrm{C} \mathrm{m}^{-3}$ rather than the total mass of $\mathrm{OM}$ to aid in the comparison to observations presented as OC. We assumed an OM:OC ratio of 1.8 for the conversion (El-Zanan et al., 2005; Yu et al., 2005; Zhang et al., 2005). In most regions, the IBASE has higher concentrations of both OC and EC than BBASE, especially in Eastern Europe. This is representative of the differences in the emissions inventories. Two exceptions are higher OC concentrations in western North America and Spain in the BBASE run.

A comparison of OC and EC concentrations to observations are shown in Fig. 2. These are the same observations used in Chung and Seinfeld (2002) that include data from the Interagency Monitoring of Protected Visual Environments (IMPROVE) database that consists of approximately 140 rural sites in the United States (Malm et al., 2000) along with various rural, remote and marine sites with locations and references contained in Chung and Seinfeld (2002). Sampling for IMPROVE includes twenty-four hour aerosol samples that were taken twice a week (on Wednesdays and 
Table 4. Locations of number concentration measurements used for comparison.

\begin{tabular}{|c|c|c|c|c|c|c|c|c|}
\hline A & $\begin{array}{c}\text { Location } \\
\text { Aspvereten, Sweden }\end{array}$ & $\begin{array}{l}\text { Region } \\
\text { Europe }\end{array}$ & $\begin{array}{c}\text { Reference } \\
\text { Van Dingenen, et al., } 2004\end{array}$ & $\begin{array}{c}\text { Time } \\
\text { Jan 2001-Dec } 2001\end{array}$ & $\begin{array}{c}\text { Latitude } \\
58.8\end{array}$ & $\begin{array}{c}\text { Longitude } \\
69.4\end{array}$ & $\begin{array}{c}\text { Elevation }(\mathrm{m}) \\
20\end{array}$ & $\begin{array}{c}\mathrm{CN}\left(\mathrm{cm}^{-3}\right) \\
2000\end{array}$ \\
\hline B & Harwell, United Kingdom & Europe & Van Dingenen, et al., 2004 & May $1998-$ Nov 2000 & 51.6 & -1.3 & 125 & 3000 \\
\hline $\mathrm{C}$ & Hohenpeissenberg, Germany & Europe & Van Dingenen, et al., 2004 & Apr 1998-Aug 2000 & 47.8 & 11.0 & 988 & 2500 \\
\hline $\mathrm{D}$ & Melpitz, Germany & Europe & Van Dingenen, et al., 2004 & Dec 1996-Nov 1997 & 51.5 & 12.9 & 86 & 5600 \\
\hline $\mathrm{E}$ & Ispra, Italy & Europe & Van Dingenen, et al., 2004 & Feb 2000-Dec 2000 & 45.8 & 8.6 & 209 & 9000 \\
\hline $\mathrm{F}$ & Thompson Farm, New Hampshire, US & North America & http://airmap.unh.edu & $2001-2005$ & 43.1 & -71.0 & 75 & 7250 \\
\hline G & Lamont, Oklahoma, US & North America & http://www.cmdl.noaa.gov/aero/data/ & 1996-2004 & 36.5 & -97.5 & 318 & 5200 \\
\hline $\mathrm{H}$ & Bondville, Illinois, US & North America & http://www.cmdl.noaa.gov/aero/data/ & $1994-2005$ & 40.1 & -88.3 & 230 & 3700 \\
\hline I & Sable Island, Nova Scotia, Canada & North America & http://www.cmdl.noaa.gov/aero/data/ & $1992-1999$ & 43.9 & -60.0 & 5 & 850 \\
\hline $\mathrm{J}$ & Trinidad Head, California, US & North America & http://www.cmdl.noaa.gov/aero/data/ & $2002-2005$ & 41.1 & -124.2 & 107 & 590 \\
\hline $\mathrm{K}$ & American Samoa & Remote & http://www.cmdl.noaa.gov/aero/data/ & $1995-2005$ & -14.2 & -170.5 & 42 & 220 \\
\hline $\mathrm{L}$ & South Pole & Remote & http://www.cmdl.noaa.gov/aero/data/ & $1995-2005$ & -90.0 & 102.0 & 2810 & 100 \\
\hline M & Point Barrow, Alaska, US & Remote & http://www.cmdl.noaa.gov/aero/data/ & $1995-2005$ & 71.3 & -156.6 & 11 & 110 \\
\hline $\mathrm{N}$ & Mauna Loa, Hawaii, US & Free Troposphere & http://www.cmdl.noaa.gov/aero/data/ & 1995-2005 & 19.5 & -155.6 & 3397 & 330 \\
\hline $\mathrm{O}$ & Jungfraujoch, Switzerland & Free Troposphere & Van Dingenen, et al., 2004 & Jun 1997-May 1998 & 47.6 & 8.0 & 3580 & 525 \\
\hline
\end{tabular}

a) BBASE OC

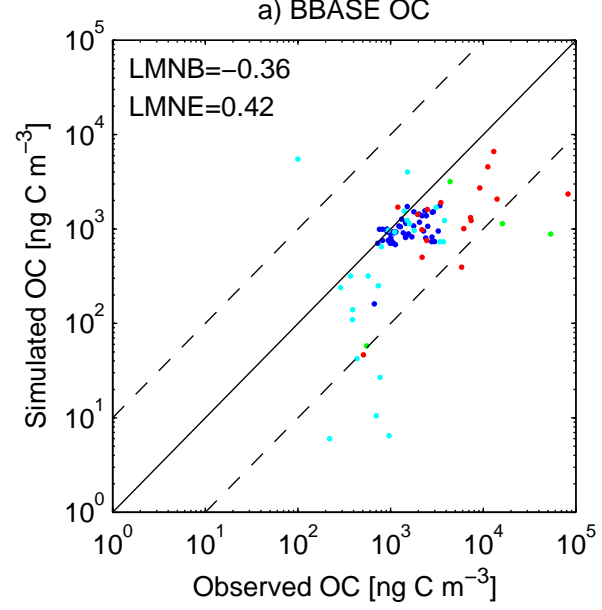

c) IBASE OC

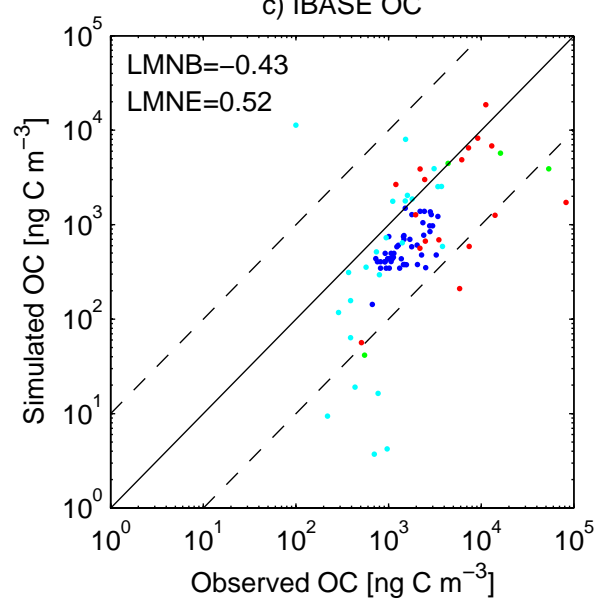

b) BBASE EC

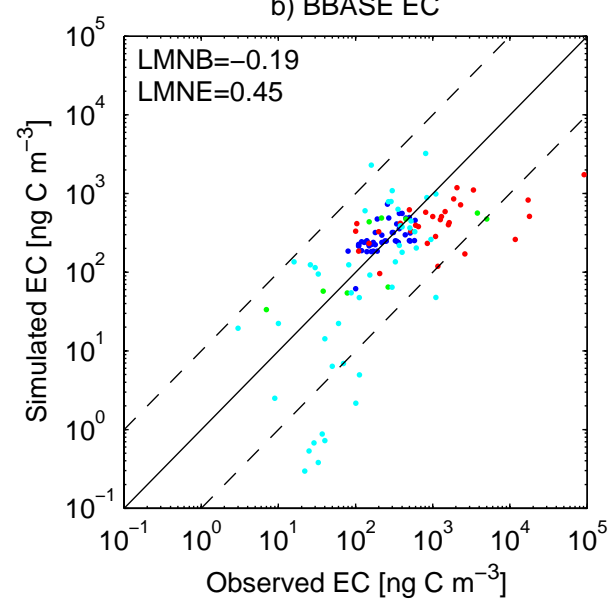

d) IBASE EC

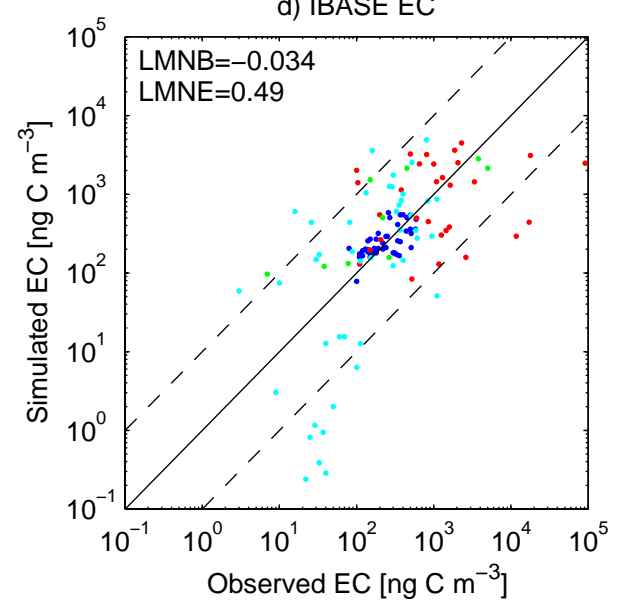

Fig. 2. OC ( $\mathrm{ng} \mathrm{C} \mathrm{m}^{-3}$ at $298 \mathrm{~K}$ and $\left.1 \mathrm{~atm}\right)$ and $\mathrm{EC} \mathrm{(ng} \mathrm{C} \mathrm{m}{ }^{-3}$ at $298 \mathrm{~K}$ and $\left.1 \mathrm{~atm}\right)$ mass comparison to observations for BBASE (a and b) and IBASE (c and d) runs. Solid line shows a 1:1 ratio and dashed line show ratios of 10:1 and 1:10. Sites taken from Chung and Seinfeld (2002). Log-mean normalized bias (LMNB) and log-mean normalized error (LMNE) given on each panel. Blue dots represent comparisons with the IMPROVE database, red dots with rural sites, green with remote sites, and cyan with marine sites (Chung and Seinfeld, 2002). IMPROVE data is a 3 year average and is compared to the 1 year average of the model. The sampling periods of the rural, remote and marine data is given in Tables 10-15 in (Chung and Seinfeld, 2002) and the model is averaged over the same time-period as the sample. 
Saturdays). The observation data are averaged over 3 years from March 1996 to February 1999. The sampling of the rural, remote and marine sites are averaged over various time periods and details are given in Tables 10-15 in Chung and Seinfeld (2002). The results of the IBASE simulation are similar to the simulations in Chung and Seinfeld (2002) with the same mass emissions rates in the same host GCM; however Chung and Seinfeld (2002) do not include aerosol size resolution and we use an OM:OC ratio of 1.8 rather than 1.3 in Chung and Seinfeld (2002), so our simulated OC values are approximately $30 \%$ smaller. In general, the results for IBASE are similar to that of Chung and Seinfeld (2002), with several locations having observed values more than a factor of ten greater than the simulated values in remote and marine areas. In general, the data in the IMPROVE database falls most closely to the 1:1 line and better agreement is shown for the EC than for OC. The BBASE simulation shows better agreement for OC with the IMPROVE database due to the higher levels of OM in the western United States. It should be noted that the methods for quantifying $\mathrm{BC} / \mathrm{EC}$ for the observations networks and the emissions inventories vary by a factor of two (Andreae and Gelencser, 2006; Heintzenberg et al., 2006; Subramanian et al., 2006).

To assess the comparison, the log-mean normalized bias (LMNB) and log-mean normalized error (LMNE) for the comparisons (data from all networks lumped together) are included on each panel. The simulations using both inventories are biased low for OC with LMNB of -0.36 and -0.46 corresponding to underpredictions by factors of 2.3 and 2.9 for the BBASE and IBASE simulations. The predictions of EC are less biased with LMNB of -0.19 and -0.034 corresponding to underpredictions by factors of 1.5 and 1.1 for the BBASE and IBASE simulations. The LMNE for all simulations are similarly high, between 0.42 and 0.52 . This means that the model predictions are, on average, within observed values to a factor of 3 .

\subsection{Aerosol number}

Figure 3 shows the annual-average predicted aerosol number (condensation nuclei, $\mathrm{CN}$ ) concentration $\left(\mathrm{cm}^{-3}\right.$ with $10 \mathrm{~nm}$ lower cutoff) for the model surface layer from the NOCARB, BBASE and IBASE simulations. The changes in $\mathrm{CN}$ concentration due to addition of carbonaceous aerosol is the difference between the BBASE or IBASE simulation and the NOCARB simulation. The largest increases in aerosol number occur in the biomass burning regions of tropical South America, Africa and Southeast Asia. The addition of primary carbonaceous aerosol in these regions causes $\mathrm{CN}$ prediction to increase by more than a factor of 20 in some places. Recent work, however, suggests that $\mathrm{CN}$ concentrations in these areas may be overpredicted, as the size distribution of primary particles from biomass burning more likely have a number median diameter on the order of $100 \mathrm{~nm}$ rather than the $25 \mathrm{~nm}$ number median diameter used here (Rissler et al.,

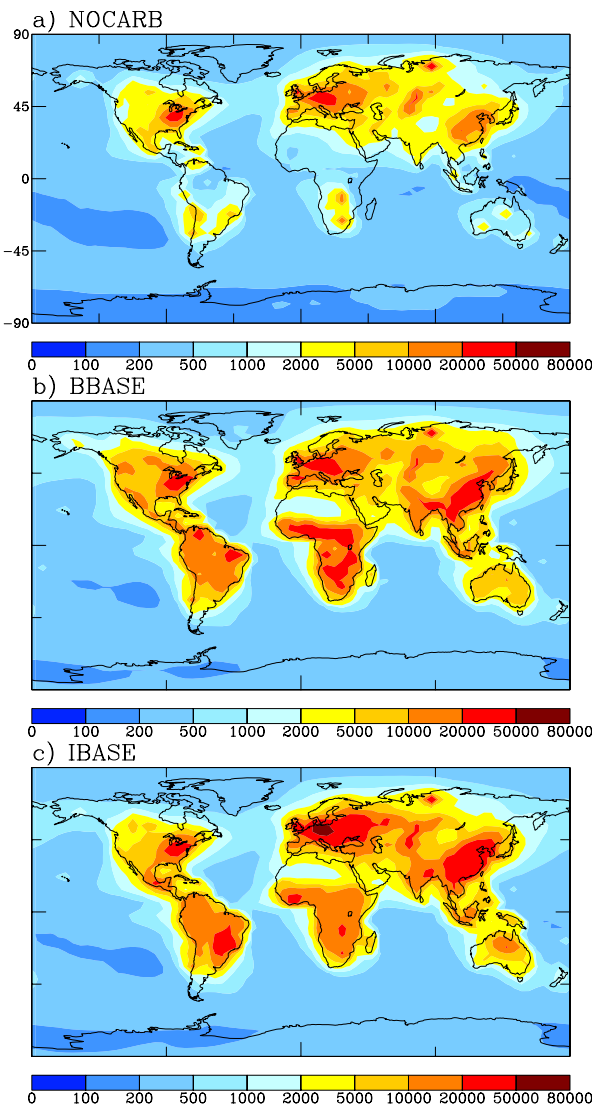

Fig. 3. Annually-averaged $\mathrm{CN}$ concentrations $\left(\mathrm{cm}^{-3}\right.$ at $298 \mathrm{~K}$ and $1 \mathrm{~atm})$ for NOCARB, BBASE and IBASE simulations.

2004; Rissler et al., 2006). Other notable increases in CN occur in polluted regions, particularly India and China where $\mathrm{CN}$ increase by a factor of $2-5$ with the addition of the primary carbonaceous aerosol. Not shown in Fig. 3 is the sensitivity of $\mathrm{CN}$ concentrations to the assumptions about mixing state and organic solubility (BCEXT, ICEXT, BCINS, and ICINS simulations). The $\mathrm{CN}$ concentrations were quite insensitive to these assumptions with no more than a $10 \%$ change in $\mathrm{CN}$ in any model grid cell and less than a $1 \%$ change in $\mathrm{CN}$ globally averaged.

We have assembled a set of long-term $\mathrm{CN}$ observations to compare to our simulations, shown in Table 4. The data we have chosen was restricted to sites outside of urban areas with a minimum sample time of about one year. The sites included are part of a European network of sites presented in Van Dingenen et al. (2004), the Global Monitoring Division (GMD) of the Earth Systems Research Laboratory (Schnell, 2003) (http://www.esrl.noaa.gov/gmd/) and the Thompson Farm site of AIRMAP (http://airmap.unh.edu/). The CN observations were done using a condensation nucleus counter (CNC) in the case of the GMD and AIRMAP data and using a $\mathrm{CNC}$ with various size scanning devices in the case of the European sites. The low limit cutoff for the CNCs in 

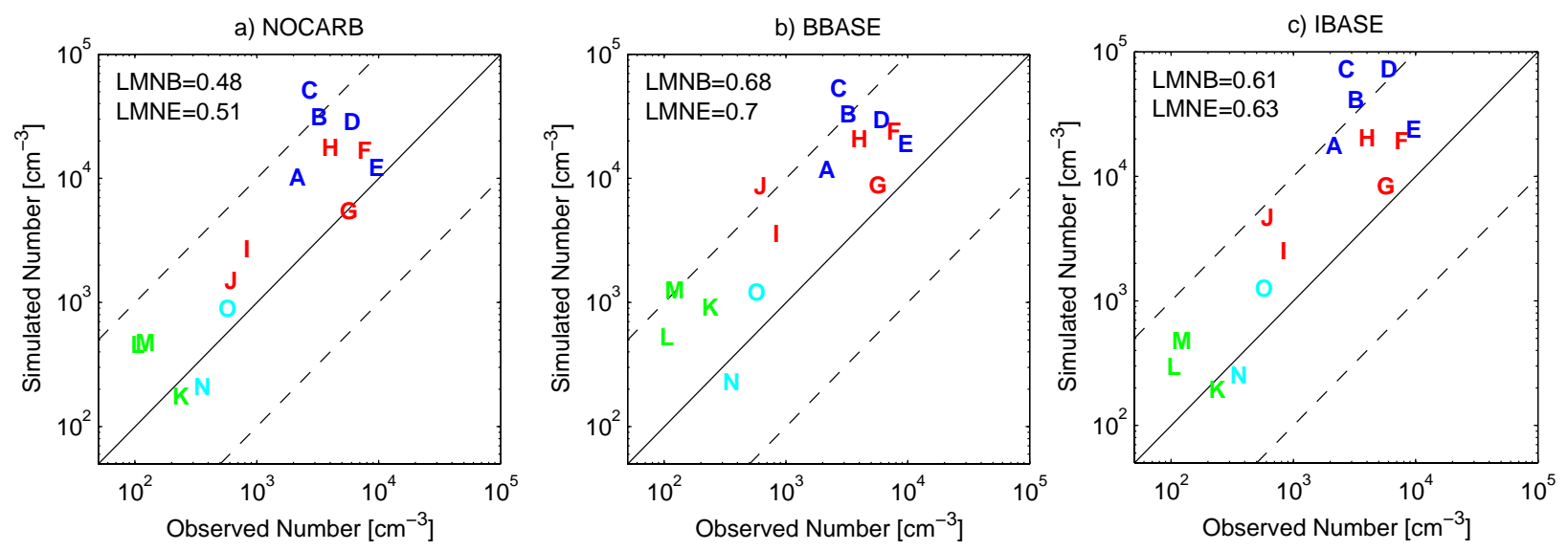

Fig. 4. Comparison of simulated aerosol number concentrations to observed number concentrations for (a) NOCARB, (b) BBASE and (c) IBASE simulations $\left(\mathrm{cm}^{-3}\right.$ at $298 \mathrm{~K}$ and $\left.1 \mathrm{~atm}\right)$. Solid line shows a 1:1 ratio and dashed line show ratios of 10:1 and 1:10. The letters refer to the locations presented in Table 3. Blue letters refer to European sites. Red letters refer to North American sites. Green letters refer to remote sites. Cyan letters refer to free tropospheric sites. Log-mean normalized bias (LMNB) and log-mean normalized error (LMNE) given on each panel.

the GMD and AIRMAP data is $10 \mathrm{~nm}$ (which corresponds to the lower size limit of the model). The lower size limit for the CNCs used in the Van Dingenen et al. (2004) paper vary, however, they have corrected their number counts for a lower cutoff of $10 \mathrm{~nm}$ using the size distribution measurements. The comparison of CN measured at these sites to the NOCARB, BBASE and IBASE simulation results is shown in Fig. 4. The log-mean normalized bias (LMNB) and log-mean normalized error (LMNE) for the comparisons are included on each panel. In general, the model tends to overpredict the $\mathrm{CN}$ concentrations in these areas even without carbonaceous aerosol included. The LMNB for the NOCARB run is 0.48 so on average the model overpredicts by a factor of $10^{0.48}$ or 3. This may be a consequence of the assumption that $3 \%$ of sulfur mass from anthropogenic emissions is assumed to be emitted as aerosol sulfate with ultrafine sizes (Adams and Seinfeld, 2003). In Adams and Seinfeld (2002), it was shown that most of the $\mathrm{CN}$ in polluted regions of the model is from primary sulfate rather than from nucleation. This implies that either too much of the sulfate mass is being emitted as primary sulfate or the primary sulfate particles are emitted at sizes that are too small. Adding primary carbonaceous emissions has a range of impacts on predicted $\mathrm{CN}$ concentrations from no change to increases of more than a factor of 5 at a given site. Because the NOCARB simulation already overpredicted $\mathrm{CN}$, the addition of primary carbonaceous aerosol causes the model to overpredict further $\mathrm{CN}$ concentrations in some areas. The LMNB for the BBASE and IBASE runs are 0.68 and 0.61 corresponding to average overpredictions by factors of 4.8 and 4.1, respectively. The LMNE is essentially the same as the LMNB for each simulation because the model overpredicts aerosol number at nearly every location. In the small number of comparisons shown, the IBASE simu- lation predicted the concentrations of remote and free tropospheric areas more accurately than polluted areas, whereas this trend is not as clear in the BBASE simulations. This may be due to the increase in emissions from developing areas in the Bond et al. (2004) inventory. The bias in CN by the model is large and we are currently addressing this in our future work.

In order to determine if the model is representing the $\mathrm{CCN}$ concentrations more accurately than $\mathrm{CN}$ concentrations, we have done comparisons of the aerosol size distribution. Figures 5 and 6 show a comparison of simulated to observed aerosol number size distributions at four of the locations (Jungfraujoch, Aspvreten, Harwell and Hohenpeissenberg) from Van Dingenen et al. (2004) and Putaud et al. (2003) for June, July and August, and December, January and February, respectively. Both simulations and observations show the number size distribution as a function of dry diameter with the exception of the observations at Harwell, which are given as ambient diameter. The data in Van Dingenen et al. (2004) is given as average distributions for the morning, afternoon and night. We have plotted the mean values of these three distributions. The total number at all four locations were shown to be overpredicted in all model simulations in Fig. 4. Figures 5 and 6 are consistent with this with the NOCARB, BBASE and IBASE simulations overpredicting the aerosol number in the ultrafine $\left(\mathrm{D}_{p}<100 \mathrm{~nm}\right)$ size range. The three simulations predict the size distributions more accurately for sizes larger than $100 \mathrm{~nm}$. $\mathrm{CCN}(0.2 \%)$ are, in general, particles of about $80-100 \mathrm{~nm}$ and larger, giving us confidence that our model is predicting $\mathrm{CCN}$ at these European locations more accurately than the model is predicting $\mathrm{CN}$. Also shown in Figs. 5 and 6 is that the dominating number mode at these locations for all simulations is centered around $20 \mathrm{~nm}$. This 

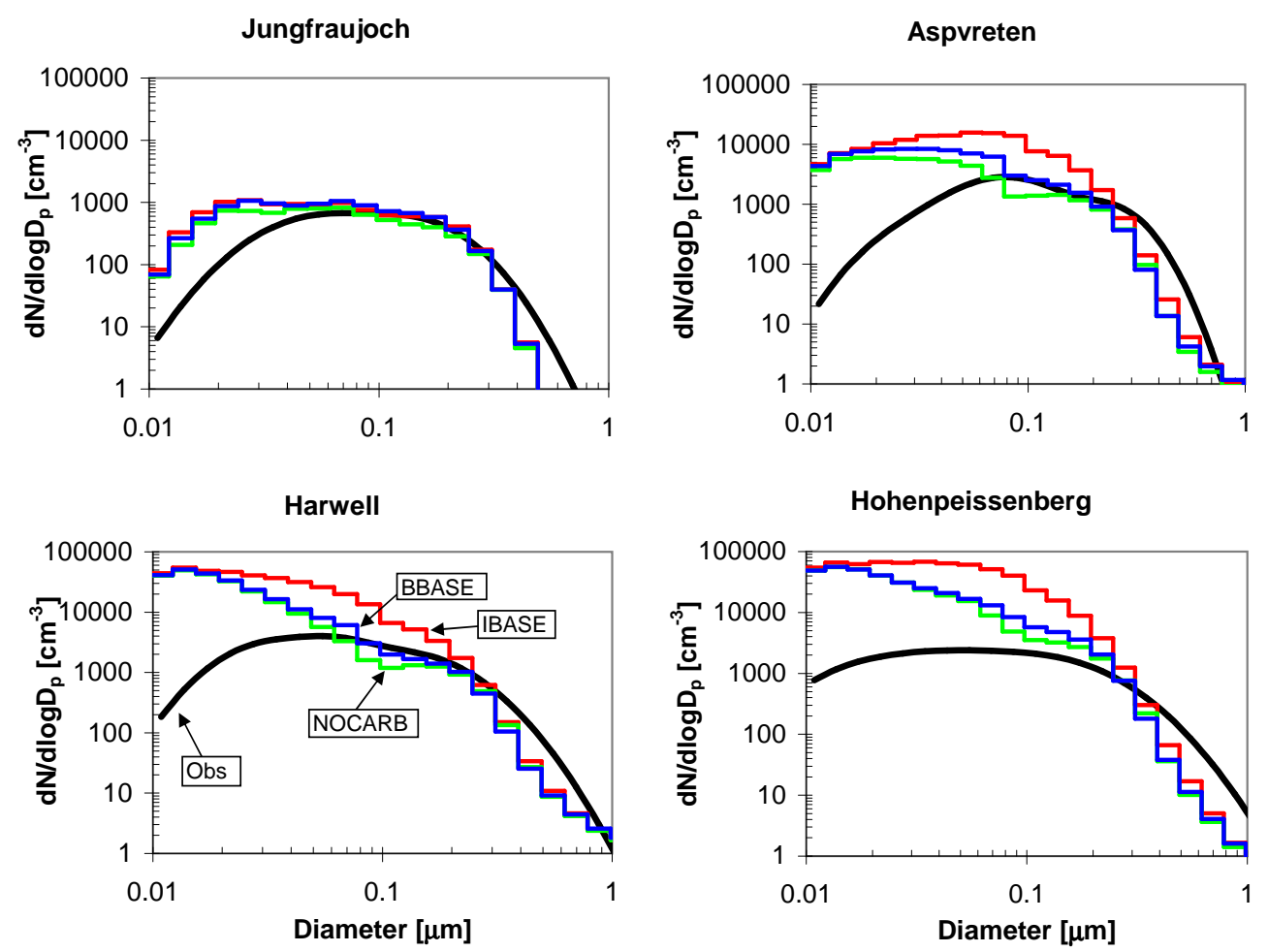

Fig. 5. Comparison of simulated number distributions to observations at four European locations published in Van Dingenen et al. (2004) and Putaud et al. (2003) for June, July and August. The x-axis is dry diameter for both the model and observations, except for the observations at Harwell which is ambient diameter. The observational data was published as a fit to three lognormal modes for morning, afternoon and night. We have plotted the mean of these three distributions.

corresponds approximately to the primary sulfate emission size, and because we do not get significant boundary layer nucleation, this is likely a major source of the $\mathrm{CN}$ overestimation. We are improving the ultrafine distribution as part of our future work.

Figure 7 shows a comparison of predicted marine number size distributions from the NOCARB, BBASE and IBASE simulations with observations compiled in Heintzenberg et al. (2000). Heintzenberg et al. (2000) collected a large set of observations of marine aerosol size distributions and summarized them by fitting the aerosol number distributions to two lognormal modes for each latitudinal zone. These data came from a wide array of sampling sites and field campaigns and used many different sampling instruments. The latitudinal bands are $15^{\circ}$ wide with no data between $75^{\circ} \mathrm{S}-90^{\circ} \mathrm{S}$ and $60^{\circ} \mathrm{N}-75^{\circ} \mathrm{N}$. The $15^{\circ}$ by $15^{\circ}$ grid cells from which the data were obtained is presented in their Fig. 1. Rather than using all ocean grid cells for comparison, we generally used model results from the same $15^{\circ}$ by $15^{\circ}$ regions where observations were collected. However, some of the $15^{\circ}$ by $15^{\circ}$ grid areas include continental areas (e.g. observations from Mace Head, Ireland are in the same $15^{\circ}$ by $15^{\circ}$ grid cell as most of the British Isles). Because the GCM grid resolution is finer, we exclude these continental sub-areas from our comparison as they greatly increase (and bias) ultrafine number concentrations. For the $0^{\circ}$ to $15^{\circ} \mathrm{N}$, we used the model predicted average values from the wet season (June-August), when these particular observations were taken, to remove biomass burning influence from the marine aerosol.

Figure 7 shows that, in most latitude bands, the model does a good job of representing the bimodal size distribution represented by the Heintzenberg et al. (2000) data. Throughout most the Northern Hemisphere and also in the $45^{\circ} \mathrm{S}-$ $30^{\circ} \mathrm{S}$ latitude band, the addition of carbonaceous particles increases the number of particles significantly; throughout the rest of the Southern Hemisphere the contribution of carbonaceous aerosol is minor. Moreover, it can be seen that the "Hoppel Gap" between the two modes of the distribution shifts toward larger sizes in the simulations with carbonaceous aerosol. The location of the Hoppel Gap depends on the average activation diameter, so this shift is the direct result of the mixed carbonaceous/sulfate/sea-salt particles being somewhat less hygroscopic than the sulfate/sea-salt only particles. This influence on the activation diameter can be seen even in the southernmost latitude bands. In Fig. 7, all of the simulations overpredict at the North Pole, underpredict in the Southern Hemisphere and compare best in the Northern Hemisphere mid-latitude bands. Averaging over all latitude 

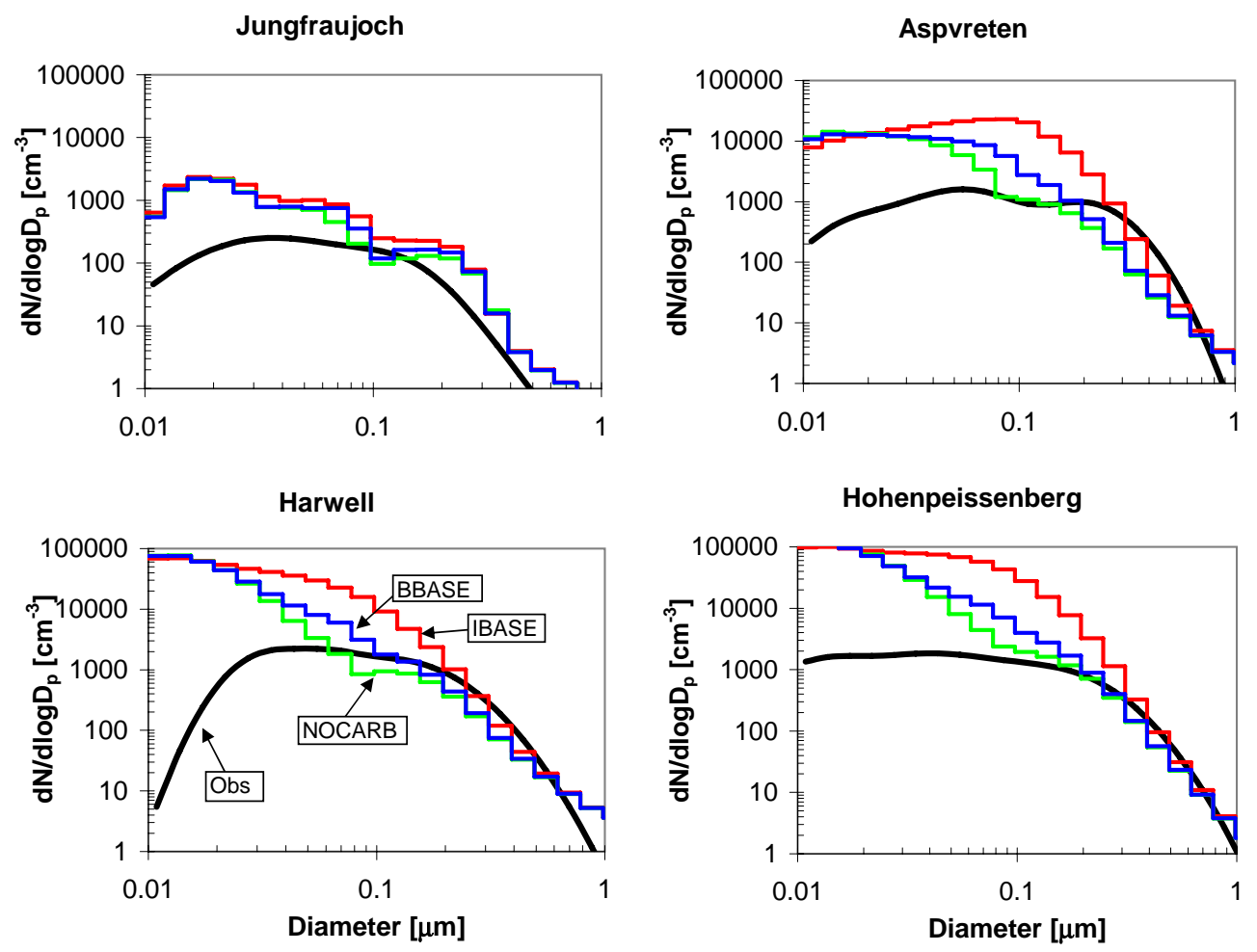

Fig. 6. Comparison of simulated number distributions to observations at four European locations published in Van Dingenen et al. (2004) and Putaud et al. (2003) for December, January and February. The x-axis is dry diameter for both the model and observations, except for the observations at Harwell which is ambient diameter. The observational data was published as a fit to three lognormal modes for morning, afternoon and night. We have plotted the mean of these three distributions.

bands, the BBASE simulation overpredicts total number by $30 \%$, the IBASE overpredicts by $15 \%$ and the NOCARB simulation underpredicts by $10 \%$. This contrasts with the results shown in Fig. 4, where the model largely overpredicts the total number of particles in most areas. It is possible that because these marine areas are away from large primary particle sources, the overprediction of particles near sources has been dampened by aerosol number removal processes such as coagulation and deposition.

\subsection{Cloud condensation nuclei}

In this section we explore $\mathrm{CCN}$ predictions by the model and test the sensitivity of $\mathrm{CCN}$ to organic solubility and mixing assumptions. Although the model overpredicted CN globally, the model showed much less bias in the accumulation mode number in Figs. 5 through 7. Furthermore, CCN concentrations tend to vary sub-linearly with $\mathrm{CN}$ concentrations allowing $\mathrm{CCN}$ errors to be, in general, smaller than $\mathrm{CN}$ errors.

The annual-average $\mathrm{CCN}$ concentrations at $0.2 \%$ supersaturation $(\mathrm{CCN}(0.2 \%))$ for the model surface level of the NOCARB, BBASE, BCINS, BCEXT, IBASE, ICINS and ICEXT simulations are shown in Fig. 8. The $\mathrm{CCN}(0.2 \%)$ concentrations are found using modified Köhler theory as discussed earlier with the annually averaged size distributions and chemical compositions. Using average size distributions and compositions to calculate average $\mathrm{CCN}$ concentrations rather than using the average of the instantaneous $\mathrm{CCN}$ concentrations gave results with error on the order of $2 \%$ globally when tested across a three month period. The addition of the Bond et al. (2004) primary carbonaceous emissions to the NOCARB model simulation (BBASE) increases $\mathrm{CCN}(0.2 \%)$ by $65 \%$ globally averaged. The addition of the IPCC (2001) primary carbonaceous emissions to the NOCARB model simulation (IBASE) increases $\mathrm{CCN}(0.2 \%)$ by $89 \%$ globally averaged. The differences in $\mathrm{CCN}(0.2 \%)$ between the BBASE and IBASE are notable in eastern Europe and the Amazon basin where IBASE predicts higher $\mathrm{CCN}(0.2 \%)$ concentrations and in western North America where BBASE predicts higher $\mathrm{CCN}(0.2 \%)$ concentrations. These results confirm that, for the base case assumptions, the contribution of primary carbonaceous aerosol is quite large and cannot be ignored. However, it is unclear from the base case simulations alone how much the increase in $\mathrm{CCN}$ from primary carbonaceous aerosol comes from the addition of new particles (carbonaceous seeding effect) verses the addition of more solute (organic solute effect). To understand this, we look at the sensitivity of our predicted $\mathrm{CCN}$ to 

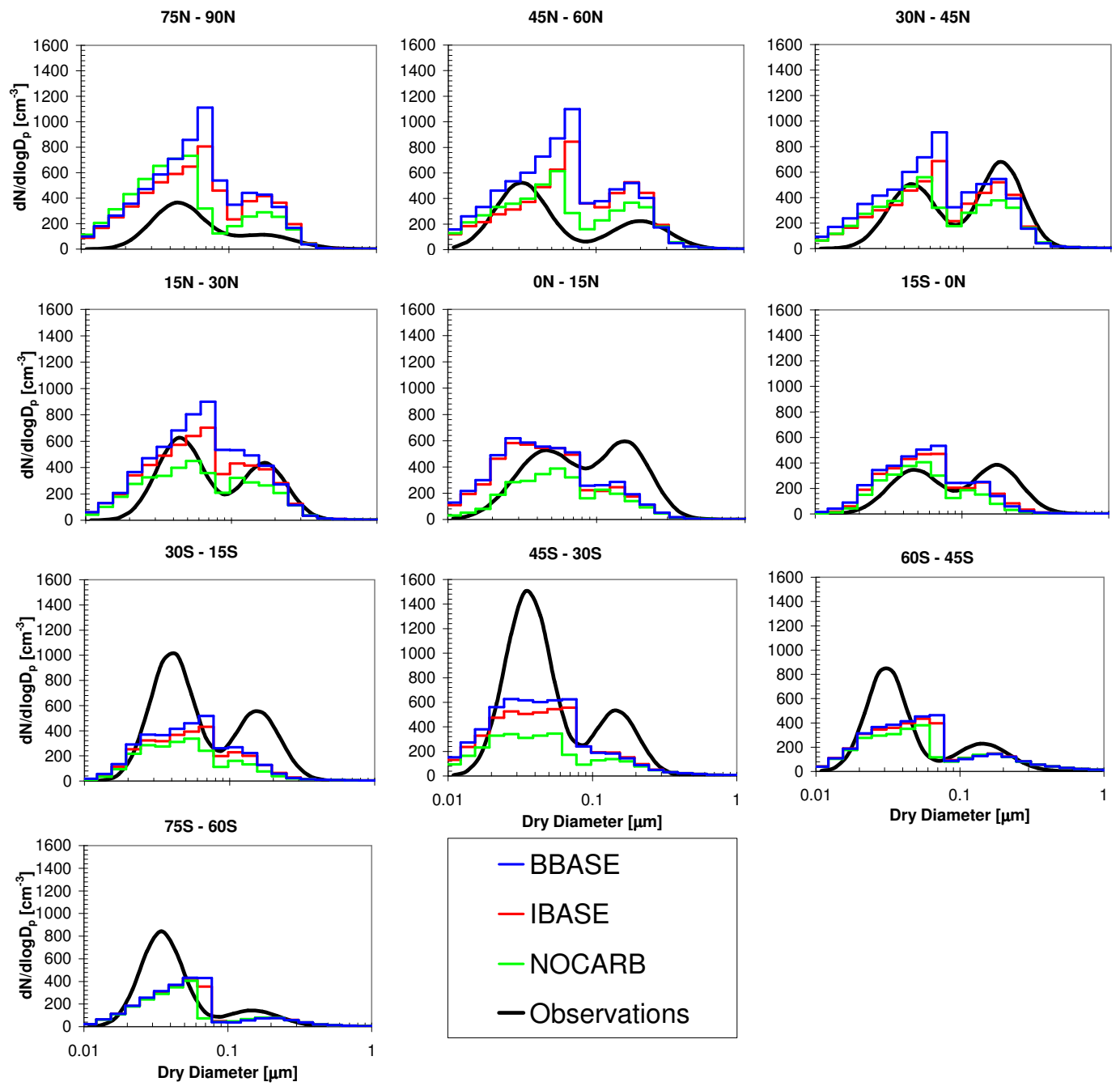

Fig. 7. Comparison of simulated number distributions in oceanic regions to observations published in Heintzenberg et al. (2000) all data at $298 \mathrm{~K}$ and $1 \mathrm{~atm}$. The model size distributions are averaged over the oceanic grid cells where the observations occurred and are annuallyaveraged with the exception of $0^{\circ}$ to $15^{\circ} \mathrm{N}$ in which the aerosol is sample over (June-August) when the observations were taken.

organic solubility. The sensitivity of the number of CCN to the mixing assumptions is also explored.

\subsubsection{Sensitivity to OM solubility}

We tested the sensitivity of model predictions to the base case assumptions of organic solubility by assuming that all carbonaceous aerosol is insoluble in the BCINS and the ICINS simulations (see Sect. 2.4). This simultaneously gives information about the relative magnitudes of the "carbonaceous seeding effect" and the "organic solute effect" because the "organic solute effect" is turned off. The $\mathrm{CCN}(0.2 \%)$ predicted by the BCINS and ICINS are shown in Fig. 8. For the simulations using the Bond et al. (2004) carbonaceous emissions, the global-average $\mathrm{CCN}(0.2 \%)$ concentration increased from $193 \mathrm{~cm}^{-3}$ to $268 \mathrm{~cm}^{-3}$ (at 1 bar and $293 \mathrm{~K}$ ) by adding insoluble carbonaceous particles to the NOCARB simulation. By allowing most of the organics to be soluble (with the hygroscopic properties discussed in Sect. 2.3) in the BBASE run, the global-average $\mathrm{CCN}(0.2 \%)$ concentration increases to $320 \mathrm{~cm}^{-3}$. This shows that for the solubility assumptions used in the BBASE run, "carbonaceous seeding" accounts for just over half of carbonaceous aerosol's globally averaged contribution to $\mathrm{CCN}$ while the "organic solute" accounts for the remainder. This fraction varies regionally, however. In areas with large amounts of carbonaceous emissions compared to inorganics, such as central Africa, the effect of carbonaceous seeding is more modest (20-40\%) in the BCINS and ICINS simulations because there is not enough inorganic aerosol to condense onto the insoluble carbonaceous particles to make them $\mathrm{CCN}$ active. Conversely, in regions with an abundance of sulfur emissions such as 

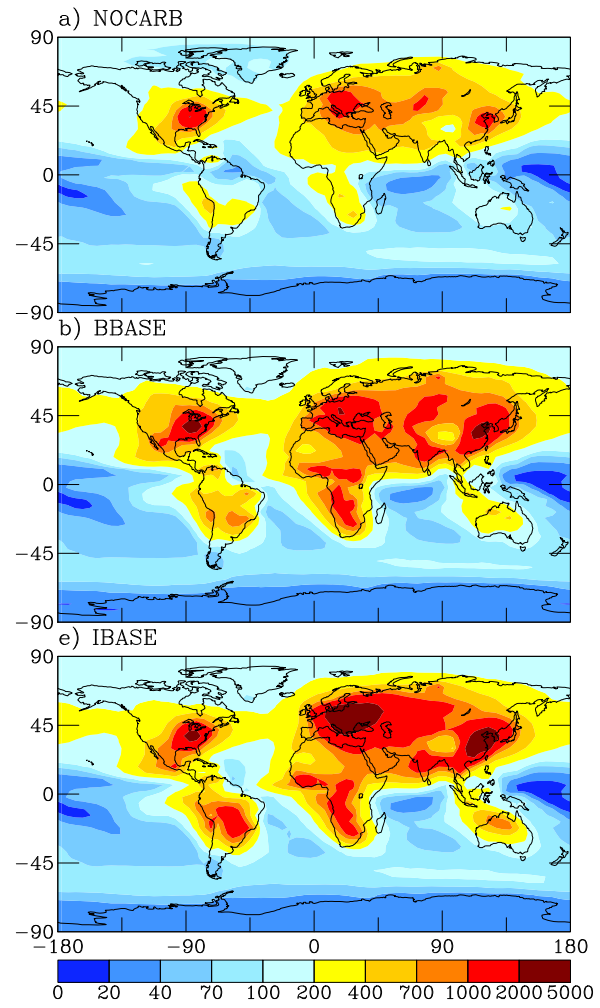

a) NOCARB
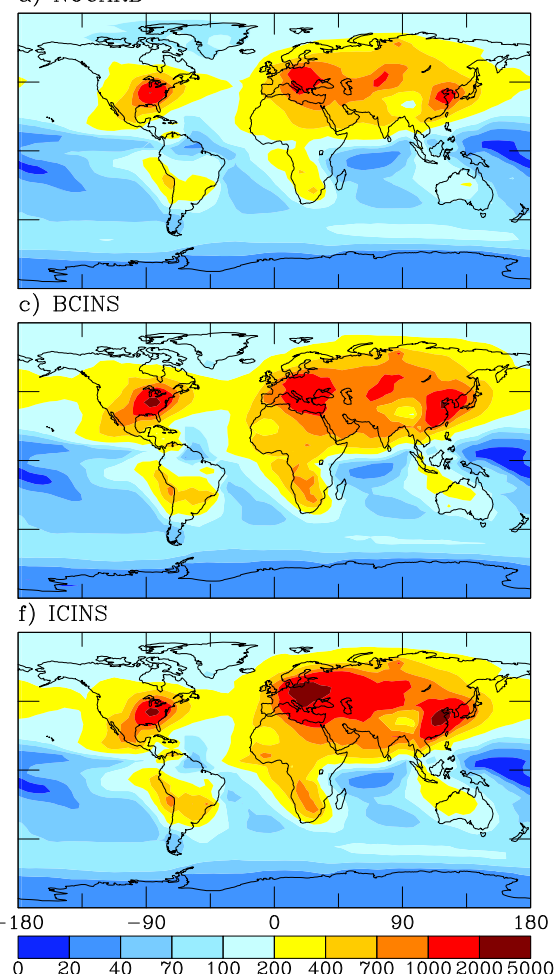
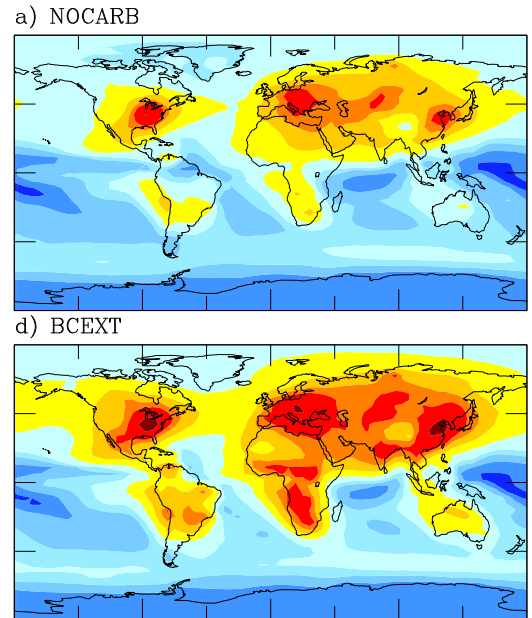

g) ICEXT

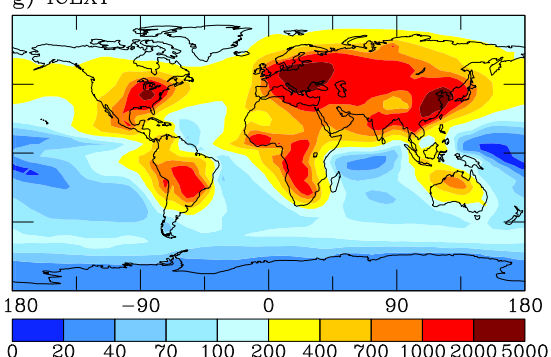

Fig. 8. Annually-averaged $\mathrm{CCN}$ concentrations at $0.2 \%$ supersaturation $\left(\mathrm{cm}^{-3}\right.$ at $298 \mathrm{~K}$ and $\left.1 \mathrm{~atm}\right)$ for the surface layer for the NOCARB, BBASE, BCEXT, IBASE, ICINS and ICEXT simulations.

the western United States or Western Europe, the "carbonaceous seeding effect" dominates the increase of $\mathrm{CCN}$ from carbonaceous emissions (responsible for $>70 \%$ of CCN enhancement by carbonaceous aerosol). Similar results are found for the simulations using the IPCC (2001) carbonaceous emissions. The global-average $\mathrm{CCN}(0.2 \%)$ increased from $193 \mathrm{~cm}^{-3}$ to $295 \mathrm{~cm}^{-3}$ by adding insoluble carbonaceous particles to the NOCARB simulation. By allowing carbonaceous aerosol to be soluble (with the hygroscopic properties discussed in Sect. 2.3) in the IBASE run the $\mathrm{CCN}(0.2 \%)$ increased to $365 \mathrm{~cm}^{-3}$. In this globally averaged case, "carbonaceous seeding" again accounts for just over half of the increase in $\mathrm{CCN}(0.2 \%)$ due to carbonaceous particles.

There is a relatively large uncertainty in the solubility and ionic nature of organic matter (Kanakidou et al., 2005); however, varying the solubility/hygroscopicity of organic matter in these simulations from largely soluble to completely insoluble changed the number of $\mathrm{CCN}(0.2 \%)$ predicted by the simulations by less than $20 \%$ globally averaged, with up to $50 \%$ reductions in biomass burning areas and smaller reductions in high sulfate areas. The range of uncertainty in organic solubility and ionic ability explored here likely spans beyond the range of the real atmosphere. With this we would expect that the uncertainty in $\mathrm{CCN}(0.2 \%)$ due to uncertainty in organic solubility is significantly less than $20 \%$.

\subsubsection{Sensitivity to mixing assumption}

In the BCEXT and ICEXT simulations we assume that the carbonaceous aerosol is externally mixed during wet removal processes (see Sect. 2.4). The four populations are, however, still assumed to be internally mixed during aerosol microphysical processes so their sizes may change due to coagulation, condensation and aqueous oxidation. The $\mathrm{CCN}(0.2 \%)$ concentrations of these two simulations are shown in Fig. 8. For both emissions sets, the externally mixed cases show slightly higher $\mathrm{CCN}(0.2 \%)$ concentrations than the base case scenarios. This happens because for most of the aerosol distributions predicted by the model, assuming the particles are externally mixed when calculating $\mathrm{CCN}(0.2 \%)$ yields approximately the same number of $\mathrm{CCN}$ as assuming that the particles are internally mixed. This is shown by applying the externally mixed assumption to calculate the $\mathrm{CCN}(0.2 \%)$ from BBASE and IBASE size distributions and chemical compositions offline rather than using the internally mixed assumption. In doing this the $\mathrm{CCN}(0.2 \%)$ changes from $320 \mathrm{~cm}^{-3}$ to $318 \mathrm{~cm}^{-3}$ for BBASE and $365 \mathrm{~cm}^{-3}$ to $354 \mathrm{~cm}^{-3}$ for IBASE. Another reason why the BBASE and BCEXT simulations and the IBASE and ICEXT simulations 
a) Average composition

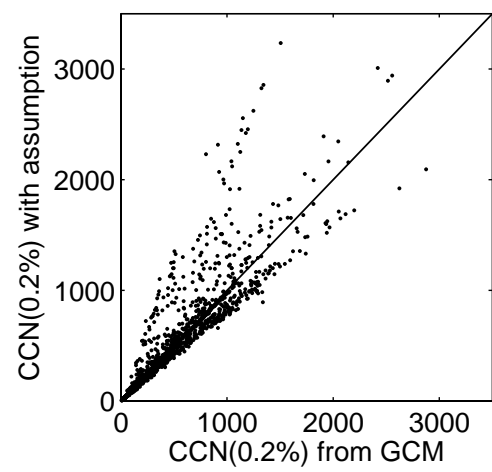

b) Average size-distribution

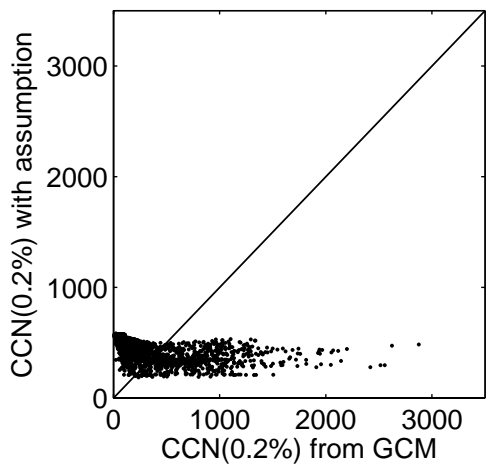

c) Bulk mass

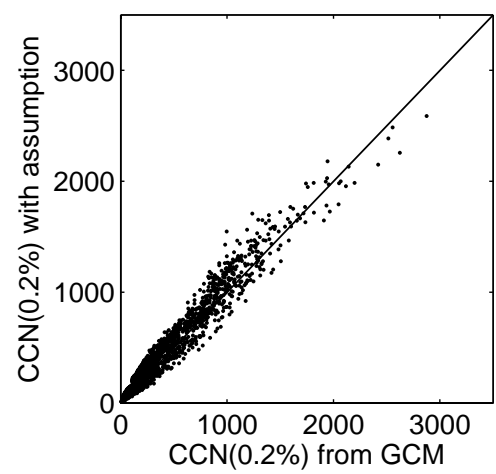

Fig. 9. (a) Model surface layer comparison of BBASE $\operatorname{CCN}(0.2 \%)$ with $\mathrm{CCN}(0.2 \%)$ simulated from BBASE assuming a globally average composition as a function of size and the size distribution varies spatially (annual average for each grid cell in the lowest model layer). (b) Comparison of BBASE $\mathrm{CCN}(0.2 \%)$ with $\mathrm{CCN}(0.2 \%)$ simulated from BBASE assuming a globally average size distribution and the size dependent chemical composition varies spatially(annual average for each grid cell in the lowest model layer). (c) Comparison of BBASE $\mathrm{CCN}(0.2 \%)$ with $\mathrm{CCN}(0.2 \%)$ simulated from BBASE assuming the globally averaged sized distribution of each species scaled by the total mass of those species in each grid cell (annual average for each grid cell in the lowest model layer).

have similar $\mathrm{CCN}$ predictions is because the aerosols are not assumed to be externally mixed during aerosol microphysical processes. This means that ultrafine carbonaceous aerosol may grow in size to sizes where the carbonaceous aerosol will activate to form $\mathrm{CCN}$ whereas if it were truly externally mixed this would not occur.

These results have shown that, for the assumptions made in the model, the number of CCN in areas well mixed and away from sources does not greatly depend on the mixing assumption as long as $\mathrm{OM}$ is soluble. If the hygroscopicity of the carbonaceous particles is reduced, then the number of $\mathrm{CCN}$ will approach the NOCARB results as the hygroscopicity/solubility is reduced to zero.

\subsection{Aerosol size distribution versus aerosol composition}

Köhler theory and observations (Dusek et al., 2006) indicate that knowing the size distribution is more important than knowing the chemical composition when predicting CCN concentrations. While Dusek et al. (2006) showed that time variability in aerosol composition at their measurement site in Germany had little effect on CCN concentrations, we use our model predictions to test the importance of regional variability in aerosol composition. Specifically, we will explore the error in $\mathrm{CCN}$ prediction that occurs when assuming global-average chemical composition or global-average size distributions rather than using location-specific information about both. All data used in this section are taken from the BBASE simulation.

For Fig. 9a, we calculated the global-average chemical composition as a function of size across the lowest model layer and used it with the predicted size distribution in each grid cell to predict the number of $\operatorname{CCN}(0.2 \%)\left(\mathrm{cm}^{-3}\right)$ in that grid cell. In Fig. 9a we have plotted these $\mathrm{CCN}$ predictions versus the $\mathrm{CCN}$ predictions using the size distribution and chemical composition predicted for each grid cell (Fig. 8b). In general, the $\mathrm{CCN}(0.2 \%)$ calculated using the global-average chemical composition agrees within a factor of two with the $\mathrm{CCN}(0.2 \%)$ calculated using no averaging. This is a much wider range of error than shown in Dusek et al. (2006) due to the wider range of compositions in the model than in the test region of Dusek et al. (2006). The areas where the $\mathrm{CCN}(0.2 \%)$ with average chemical composition overpredict are areas with large amounts of less $\mathrm{CCN}$ active carbonaceous particles such as the biomass burning influenced tropical regions. In these regions the average chemical composition is more $\mathrm{CCN}$ active than their actual chemical composition. Conversely, regions where the $\operatorname{CCN}(0.2 \%)$ with average chemical composition underpredict are areas with large amounts of inorganic species.

For Fig. 9b, we calculated the global-average size distribution across the lowest model layer and used it with the predicted chemical composition (as a function of size) in each grid cell to predict the number of $\operatorname{CCN}(0.2 \%)\left(\mathrm{cm}^{-3}\right)$ in that grid cell. We plotted these values against the $\mathrm{CCN}$ predictions using the size distribution and chemical composition predicted for each grid cell (Fig. 8b). The $\mathrm{CCN}(0.2 \%)$ using the global-average size distribution vary only between about $200 \mathrm{~cm}^{-3}$ and $600 \mathrm{~cm}^{-3}$, whereas the $\mathrm{CCN}(0.2 \%)$ predicted not using the global-averaging range from $0 \mathrm{~cm}^{-3}$ to $3000 \mathrm{~cm}^{-3}$. There is essentially no correlation between the two data sets. The areas with much more sea-salt aerosol than carbonaceous aerosol appear on the high end of the $\mathrm{CCN}(0.2 \%)$ prediction with the global average size distributions, even when their total number of particles is actually very low, such as southern hemisphere marine environments. 
On the other hand, areas that have large amounts of aerosol but a large portion of if its mass is carbonaceous aerosol, such as the tropical biomass burning regions, will have the lowest predicted $\mathrm{CCN}(0.2 \%)$ in the global-average size distribution calculation.

Figure 9c shows an additional comparison to evaluate the ability of global models without microphysics (bulk aerosol models) to calculate $\mathrm{CCN}$. In this figure, we compare the BBASE CCN $(0.2 \%)$ to $\mathrm{CCN}(0.2 \%)$ calculated assuming that the shape of the size distribution of each of the six chemical species or groups is the same as the globally averaged sizedistribution of those species, but is scaled by the total mass of each species in each grid cell. This is similar to GCM simulations that calculate the total mass of each species and then assume a size distribution of each species when calculating the CCN. Figure 9c shows that the "bulk mass" model agrees with the BBASE $\operatorname{CCN}(0.2 \%)$ with a normalized error of $35 \%$. This shows that bulk models can, in general, calculate the general spatial distribution of $\mathrm{CCN}(0.2 \%)$. There are, however, other reasons why microphysical models are advantageous over bulk models. Although the size distribution of particles for the current time period may be measured, this is not the case of past or future time periods where the size distributions may be different. The relative contribution of primary particles and nucleated particles to $\mathrm{CN}$ and $\mathrm{CCN}$ may be explored using microphysical models but cannot be in bulk models.

Obviously there are major differences between this analysis and the one shown in (Dusek et al., 2006); however, both clearly show it is impossible to predict $\mathrm{CCN}$ concentrations without an accurate size distribution. In contrast to that work, these results suggest that regional variability in aerosol composition are important in predicting CCN. In our case, up to a factor of two error is introduced when a (size-dependent) chemical composition is assumed.

\section{Conclusions}

We explored the impact of primary carbonaceous aerosol on cloud condensation nuclei $(\mathrm{CCN})$ concentrations in a global climate model with online size-resolved aerosol microphysics. Two emissions inventories of organic matter $(\mathrm{OM})$ and elemental carbon (EC) were tested in the model along with sulfate and sea-salt aerosol. Simulations were run with various assumptions of the solubility and mixing state of the carbonaceous aerosol to provide bounds on its impacts on $\mathrm{CCN}$ concentrations.

Predicted primary carbonaceous aerosol mass and aerosol number concentrations were compared to observations. Errors in predictions of $\mathrm{OC}$ and $\mathrm{EC}$ masses were a factor of 3 on average and OC predictions were biased towards too little mass whereas EC predictions showed little bias. A comparison to a network of total aerosol number measurements shows that the model predicted number concentrations were on average about a factor of 4 too high. Even without carbonaceous particles included, the number concentrations are already factor of 3 too high. A comparison of the simulated aerosol size distributions to observations at several European sites showed that the overprediction of $\mathrm{CN}$ at these sites was due to large overpredictions in the number of particles with diameters smaller than $100 \mathrm{~nm}$, whereas the accumulation mode particles were predicted much more accurately. This overprediction of $\mathrm{CN}$ may be due to the emission of too many particles through primary sulfate emissions and aided by incorrect emission size distributions of carbonaceous particles. In contrast, a comparison of $\mathrm{CN}$ to marine observations showed very little overprediction $(<30 \%)$. The sensitivity of $\mathrm{CN}$ and $\mathrm{CCN}$ to these emissions is being performed in future work.

It was found that adding primary carbonaceous aerosol increased $\mathrm{CCN}(0.2 \%)$ concentrations by $65-90 \%$, depending on which emissions dataset was used, compared with a model with sulfate and sea-salt aerosol only. The largest increases in $\mathrm{CCN}(0.2 \%)$ occurred in the biomass burning regions of South America and Africa and in regions of eastern Asia and Australia. Assuming that all carbonaceous aerosol is insoluble, rather than mostly soluble in our base case, the carbonaceous aerosol still increases $\mathrm{CCN}(0.2 \%)$ by $40-50 \%$ over the sulfate/sea-salt only simulation. This shows that around half of the increase in $\mathrm{CCN}$ due to primary carbonaceous aerosol occurs due to the addition of new aerosol particles (seeding effect) where the $\mathrm{CCN}$ are created by regardless of carbonaceous solubility/hygroscopicity (because the carbonaceous particles end up coated with hydrophilic material). The other half of the $\mathrm{CCN}$ generated by carbonaceous aerosol depends on carbonaceous solubility/hygroscopicity (solute effect). The solute effect tends to dominate (responsible for $>70 \%$ of the carbonaceous $\mathrm{CCN}$ ) more in areas where there is less inorganic aerosol than organic aerosol, such as biomass burning regions, and the seeding effect tends to dominate in areas where is more inorganic aerosol than organic aerosol, such as eastern North America. The effect of the assumption of internal versus external mixing of the carbonaceous aerosol with inorganic aerosol during cloud processes was found to have little effect on the number of CCN generated as long as the carbonaceous aerosol was mostly soluble.

To evaluate the importance of chemical composition and the aerosol size distribution globally, we calculate the $\mathrm{CCN}(0.2 \%)$ in each grid cell by using globally averaged chemical composition or globally averaged size distributions. We found that, in general, the $\mathrm{CCN}(0.2 \%)$ calculated by assuming a uniform globally averaged chemical composition for the entire globe (while using the predicted size distribution in each location) was within a factor of 2 of the $\mathrm{CCN}(0.2 \%)$ calculated with both chemical composition and size distribution information. The $\operatorname{CCN}(0.2 \%)$ calculated from assuming a uniform globally averaged size distribution for the entire globe (while using the predicted chemi- 
cal composition in each location) gave very bad results compared to the full calculation. Additionally, we tested the ability of global models that simulate only the total mass of each species to predict $\mathrm{CCN}$ by assuming the globally averaged size distribution shape for each species and recalculating the $\mathrm{CCN}(0.2 \%)$. It was found that assuming the size distribution shape of each species yields an average error of 35\% against our base simulation with size resolved aerosol microphysics.

The results of this study show that understanding primary carbonaceous aerosol is very important to understanding how humans have altered the radiative balance of the planet through emissions of particles. Specifically, this has shown that the contribution of carbonaceous particles to $\mathrm{CCN}$ is large; however, the uncertainties of the magnitude of primary organic aerosol emissions and volatility along with the generation of secondary organic aerosol are large, so this contribution to $\mathrm{CCN}$ is still quite uncertain.

Acknowledgements. This research was supported by the United States National Aeronautics and Space Administration through grant RSP-0153-0289 and by the Environmental Protection Agency through the Science to Achieve Results (STAR) Graduate Fellowship (91668201-0). The authors would like to thank A. Jefferson from NOAA for help with Global Monitoring Division (GMD) data.

Edited by: Y. Balkanski

\section{References}

Adams, P. J. and Seinfeld, J. H.: Disproportionate impact of particulate emissions on global cloud condensation nuclei concentrations, Geophys. Res. Lett., 30, ISI:000182151300004, 2003.

Adams, P. J. and Seinfeld, J. H.: Predicting global aerosol size distributions in general circulation models, J. Geophys. Res. Atmos., 107, 4370, 2002.

Albrecht, B. A.: Aerosols, Cloud Microphysics, and Fractional Cloudiness, Science, 245, 1227-1230, 1989.

Andreae, M. O. and Gelencser, A.: Black carbon or brown carbon? The nature of light-absorbing carbonaceous aerosols, Atmos. Chem. Phys., 6, 3131-3148, ISI:000239346600001, 2006.

Andreae, M. O., Jones, C. D., and Cox, P. M.: Strong present-day aerosol cooling implies a hot future, Nature, 435, 1187-1190, ISI:000230140500033, 2005.

Benkovitz, C. M., Scholtz, M. T., Pacyna, J., Tarrason, L., Dignon, J., Voldner, E. C., Spiro, P. A., Logan, J. A., and Graedel, T. E.: Global gridded inventories of anthropogenic emissions of sulfur and nitrogen, J. Geophys. Res. Atmos., 101, 29 239-29253, ISI:A1996VZ78800050, 1996.

Bond, T. C., Streets, D. G., Yarber, K. F., Nelson, S. M., Woo, J. H., and Klimont, Z.: A technology-based global inventory of black and organic carbon emissions from combustion, J. Geophys. Res. Atmos., 109, ISI:000222916600001, 2004.

Chuang, C. C., Penner, J. E., Prospero, J. M., Grant, K. E., Rau, G. H., and Kawamoto, K.: Cloud susceptibility and the first aerosol indirect forcing: Sensitivity to black carbon and aerosol concentrations, J. Geophys. Res. Atmos., 107, ISI:000180860300016, 2002.
Chung, S. H. and Seinfeld, J. H.: Global distribution and climate forcing of carbonaceous aerosols, J. Geophys. Res. Atmos., 107, ISI:000180860300016, 2002.

Clarke, A. D., Owens, S., and Zhou, J.: An ultrafine seasalt flux from breaking waves: Implications for $\mathrm{CCN}$ in the remote marine atmosphere, J. Geophys. Res. Atmos., 111, ISI:000236332000004, 2006.

Cooke, W. F., Liousse, C., Cachier, H., and Feichter, J.: Construction of a 1 degrees $\times 1$ degrees fossil fuel emission data set for carbonaceous aerosol and implementation and radiative impact in the ECHAM4 model, J. Geophys. Res.-Atmos., 104, 22 13722 162, ISI:000082789200006, 1999.

Cooke, W. F. and Wilson, J. J. N.: A global black carbon aerosol model, J. Geophys. Res.-Atmos., 101, 19395-19409, ISI:A1996VE25800041, 1996.

Dusek, U., Frank, G. P., Hildebrandt, L., Curtius, J., Schneider, J., Walter, S., Chand, D., Drewnick, F., Hings, S., Jung, D., Borrmann, S., and Andreae, M. O.: Size matters more than chemistry for cloud-nucleating ability of aerosol particles, Science, 312, 1375-1378, ISI:000237961600054, 2006.

Easter, R. C., Ghan, S. J., Zhang, Y., Saylor, R. D., Chapman, E. G., Laulainen, N. S., Abdul-Razzak, H., Leung, L. R., Bian, X. D., and Zaveri, R. A.: MIRAGE: Model description and evaluation of aerosols and trace gases, J. Geophys. Res.-Atmos., 109, ISI:000224882100001, 2004.

Eliason, T. L., Aloisio, S., Donaldson, D. J., Cziczo, D. J., and Vaida, V.: Processing of unsaturated organic acid films and aerosols by ozone, Atmos. Environ., 37, 2207-2219, ISI:000182778900004, 2003.

Eliason, T. L., Gilman, J. B., and Vaida, V.: Oxidation of organic films relevant to atmospheric aerosols, Atmos. Environ., 38, 1367-1378, ISI:000189102000013, 2004.

El-Zanan, H. S., Lowenthal, D. H., Zielinska, B., Chow, J. C., and Kumar, N.: Determination of the organic aerosol mass to organic carbon ratio in IMPROVE samples, Chemosphere, 60, 485-496, ISI:000231038200006, 2005.

FassiFihri, A., Suhre, K., and Rosset, R.: Internal and external mixing in atmospheric aerosols by coagulation: Impact on the optical and hygroscopic properties of the sulphate-soot system, Atmos. Environ., 31, 1393-1402, ISI:A1997WR16000002, 1997.

Forster, P., Ramaswamy, V., Artaxo, P., Berntsen, T., Betts, R., Fahey, D. W., Haywood, J., Lean, J., Lowe, D. C., Myhre, G., Nganga, J., Prinn, R., Raga, G., Schulz, M., and Dorland, R. V.: Changes in Atmospheric Constituents and in Radiative Forcing, in Climate Change 2007: The Physical Science Basis. Contribution of Working Group I to the Fourth Assessment Report of the Intergovernmental Panel on Climate Change, edited by: S. Solomon, D. Qin, M. Manning, Z. Chen, M. Marquis, K. B. Averyt, M. Tignor, and H. L. Miller, Cambridge University Press, Cambridge, United Kingdom and New York, NY, USA, pp. 2007.

Ghan, S., Easter, R., Hudson, J., and Breon, F. M.: Evaluation of aerosol indirect radiative forcing in MIRAGE, J. Geophys. Res.Atmos., 106, 5317-5334, ISI:000167635900016, 2001.

Gong, S. L., Barrie, L. A., Blanchet, J. P., von Salzen, K., Lohmann, U., Lesins, G., Spacek, L., Zhang, L. M., Girard, E., Lin, H., Leaitch, R., Leighton, H., Chylek, P., and Huang, P.: Canadian Aerosol Module: A size-segregated simulation of atmospheric aerosol processes for climate and air quality mod- 
els - 1. Module development, J. Geophys. Res.-Atmos., 108, ISI:000181553400003, 2003.

Hanel, G.: Single-Scattering Albedo of Atmospheric AerosolParticles as a Function of Relative Humidity, J. Atmos. Sci., 33, 1120-1124, ISI:A1976BV24200020, 1976.

Hansen, J., Russell, G., Rind, D., Stone, P., Lacis, A., Lebedeff, S., Ruedy, R., and Travis, L.: Efficient 3-Dimensional GlobalModels for Climate Studies - Model-I and Model-II, Mon. Wea. Rev., 111, 609-662, ISI:A1983QU10600001, 1983.

Heintzenberg, J., Covert, D. C., and Van Dingenen, R. V.: Size distribution and chemical composition of marine aerosols: A compilation and review, Tellus B, 52, 1104-1122, 2000.

Heintzenberg, J., Leck, C., Birmili, W., Wehner, B., Tjernstrom, M., and Wiedensohler, A.: Aerosol number-size distributions during clear and fog periods in the summer high Arctic: 1991, 1996 and 2001, Tellus B, 58, 41-50, ISI:000235520500005, 2006.

Herzog, M., Weisenstein, D. K., and Penner, J. E.: A dynamic aerosol module for global chemical transport models: Model description, J. Geophys. Res.-Atmos., 109, 18 202-18 213, 2004.

Hitzenberger, R., Berner, A., Giebl, H., Kromp, R., Larson, S. M., Rouc, A., Koch, A., Marischka, S., and Puxbaum, H.: Contribution of carbonaceous material to cloud condensation nuclei concentrations in European background (Mt. Sonnblick) and urban (Vienna) aerosols, Atmos. Environ., 33, 2647-2659, ISI:000080975600005, 1999.

IPCC: Intergovernmental Panel on Climate Change 2001: The Scientific Basis - Technical Summary, 2001.

Jacobson, M. Z.: Analysis of aerosol interactions with numerical techniques for solving coagulation, nucleation, condensation, dissolution, and reversible chemistry among multiple size distributions, J. Geophys. Res. Atmos., 107, ISI:000180428300033, 2002.

Jacobson, M. Z.: Strong radiative heating due to the mixing state of black carbon in atmospheric aerosols, Nature, 409, 695-697, ISI:000166816400037, 2001.

Janhall, S., Jonsson, A. M., Molnar, P., Svensson, E. A., and Hallquist, M.: Size resolved traffic emission factors of submicrometer particles, Atmos. Environ., 38, 4331-4340, ISI:000223019500006, 2004.

Jung, C. H., Kim, Y. P., and Lee, K. W.: Multicomponent aerosol dynamics model with gas/particle transport and modal approach, Environ. Eng. Sci., 21, 437-450, ISI:000222488300003, 2004.

Kanakidou, M., Seinfeld, J. H., Pandis, S. N., Barnes, I., Dentener, F. J., Facchini, M. C., Van Dingenen, R., Ervens, B., Nenes, A., Nielsen, C. J., Swietlicki, E., Putaud, J. P., Balkanski, Y., Fuzzi, S., Horth, J., Moortgat, G. K., Winterhalter, R., Myhre, C. E. L., Tsigaridis, K., Vignati, E., Stephanou, E. G., and Wilson, J.: Organic aerosol and global climate modelling: a review, Atmos. Chem. Phys., 5, 1053-1123, ISI:000228024100001, 2005.

Kinne, S., Lohmann, U., Feichter, J., Schulz, M., Timmreck, C., Ghan, S., Easter, R., Chin, M., Ginoux, P., Takemura, T., Tegen, I., Koch, D., Herzog, M., Penner, J., Pitari, G., Holben, B., Eck, T., Smirnov, A., Dubovik, O., Slutsker, I., Tanre, D., Torres, O., Mishchenko, M., Geogdzhayev, I., Chu, D. A., and Kaufman, Y.: Monthly averages of aerosol properties: A global comparison among models, satellite data, and AERONET ground data, J. Geophys. Res.-Atmos., 108, ISI:000186198500001, 2003.

Koch, D.: Transport and direct radiative forcing of carbonaceous and sulfate aerosols in the GISS GCM, J. Geophys. Res.-Atmos.,
106, 20311-20332, ISI:000171044200023, 2001.

Koch, D., Jacob, D., Tegen, I., Rind, D., and Chin, M.: Tropospheric sulfur simulation and sulfate direct radiative forcing in the Goddard Institute for Space Studies general circulation model, J. Geophys. Res.-Atmos., 104, 23 799-23 822, 1999.

Laaksonen, A., Korhonen, P., Kulmala, M., and Charlson, R. J.: Modification of the Kuhler equation to include soluble trace gases and slightly soluble substances, J. Atmos. Sci., 55, 853862, ISI:000072288400011, 1998.

Liousse, C., Penner, J. E., Chuang, C., Walton, J. J., Eddleman, H., and Cachier, H.: A global three-dimensional model study of carbonaceous aerosols, J. Geophys. Res.-Atmos., 101, 1941119432, ISI:A1996VE25800042, 1996.

Lohmann, U., Feichter, J., Penner, J., and Leaitch, R.: Indirect effect of sulfate and carbonaceous aerosols: A mechanistic treatment, J. Geophys. Res.-Atmos., 105, 12 193-12 206, ISI:000087366600008, 2000.

Malm, W. C., Pitchford, M. L., Scruggs, M., Sisler, J. F., Ames, R., Copeland, S., Gebhart, K. A., and Day, D. E.: Spational and Seasonal Patterns and Temporal Variability of Haze and its Constituents in the United States: Report III, 2000.

Moise, T. and Rudich, Y.: Reactive uptake of ozone by aerosol-associated unsaturated fatty acids: Kinetics, mechanism, and products, J. Phys. Chem. Atmos., 106, 6469-6476, ISI:000176600600005, 2002.

Novakov, T. and Penner, J. E.: Large Contribution of Organic Aerosols to Cloud-Condensation-Nuclei Concentrations, Nature, 365, 823-826, ISI:A1993MD95100045, 1993.

Park, R. J., Jacob, D. J., Palmer, P. I., Clarke, A. D., Weber, R. J., Zondlo, M. A., Eisele, F. L., Bandy, A. R., Thornton, D. C., Sachse, G. W., and Bond, T. C.: Export efficiency of black carbon aerosol in continental outflow: Global implications, J. Geophys. Res.-Atmos., 110, ISI:000229829100006, 2005.

Penner, J. E., Chuang, C. C., and Grant, K.: Climate forcing by carbonaceous and sulfate aerosols, Clim. Dynamm., 14, 839-851, ISI:000076963400001, 1998.

Penner, J. E., Eddleman, H., and Novakov, T.: Towards the Development of a Global Inventory for Black Carbon Emissions, Atmos. Environ., 27, 1277-1295, ISI:A1993LJ39000013, 1993.

Petters, M. D. and Kreidenweis, S. M.: A single parameter representation of hygroscopic growth and cloud condensation nucleus activity, Atmos. Chem. Phys., 7, 1961-1971, 2007.

Pierce, J. R. and Adams, P. J.: Global evaluation of CCN formation by direct emission of sea salt and growth of ultrafine sea salt, J. Geophys. Res.-Atmos., 111, ISI:000236332000002, 2006.

Prather, M. J.: Numerical advection by conservation of secondorder moments, J. Geophys. Res.-Atmos., 91, 6671-6681, 1986.

Putaud, J. P.: A European aerosol phenomenology; physical and chemical characteristics of particulate matter at kerbside, urban, rural and background sites in Europe, 2003, European Commission, EUR 20411 EN., http://ies.jrc.cec.eu.int/Download/cc

Raymond, T. M. and Pandis, S. N.: Cloud activation of singlecomponent organic aerosols, J. Geophys. Res.-Atmos., 107, 4787-4784, 2002.

Raymond, T. M. and Pandis, S. N.: Formation of cloud droplets by multicomponent organic particles, J. Geophys. Res. Atmos., 108, 4469-4476, 2003.

Reddy, M. S. and Boucher, O.: A study of the global cycle of carbonaceous aerosols in the LMDZT general circulation model, J. 
Geophys. Res.-Atmos., 109, ISI:000222916300002, 2004.

Riemer, N., Vogel, H., and Vogel, B.: Soot aging time scales in polluted regions during day and night, Atmos. Chem. Phys., 4, 1885-1893, ISI:000223866600001, 2004.

Rissler, J., Swietlicki, E., Zhou, J., Roberts, G., Andreae, M. O., Gatti, L. V., and Artaxo, P.: Physical properties of the sub-micrometer aerosol over the Amazon rain forest during the wet-to-dry season transition - comparison of modeled and measured CCN concentrations, Atmos. Chem. Phys., 4, 2119-2143, ISI:000224840800001, 2004.

Rissler, J., Vestin, A., Swietlicki, E., Fisch, G., Zhou, J., Artaxo, P., and Andreae, M. O.: Size distribution and hygroscopic properties of aerosol particles from dry-season biomass burning in Amazonia, Atmos. Chem. Phys., 6, 471-491, ISI:000235230500001, 2006.

Rodriguez, M. A. and Dabdub, D.: A modeling study of size- and chemically resolved aerosol thermodynamics in a global chemical transport model, J. Geophys. Res.-Atmos., 109, ISI:000188672100002, 2004.

Schnell, R. C.: Chapter 3: Aerosols and Radiation, in: Climate Monitoring and Diagnostics Laboratory Summary Report No. 27, edited by: A. McComisky, 2002-2003, 2003.

Schwartz, S. E.: Uncertainty requirements in radiative forcing of climate change, J. Air Waste Ma., 54, 1351-1359, ISI:000224972400002, 2004.

Seinfeld, J. H. and Pandis, S. N.: Atmospheric Chemistry and Physics, John Wiley and Sons., New York, 784-790, 1998.

Spracklen, D. V., Carslaw, K. S., Kulmala, M., Kerminen, V. M., Mann, G. W., and Sihto, S. L.: The contribution of boundary layer nucleation events to total particle concentrations on regional and global scales, Atmos. Chem. Phys., 6, 5631-5648, ISI:000242944600002, 2006

Spracklen, D. V., Pringle, K. J., Carslaw, K. S., Chipperfield, M. P., and Mann, G. W.: A global off-line model of sizeresolved aerosol microphysics: I. Model development and prediction of aerosol properties, Atmos. Chem. Phys., 5, 22272252, ISI:000231363700002, 2005a.

Spracklen, D. V., Pringle, K. J., Carslaw, K. S., Chipperfield, M. P., and Mann, G. W.: A global off-line model of size-resolved aerosol microphysics: II. Identification of key uncertainties, Atmos. Chem. Phys., 5, 3233-3250, ISI:000233951200001, 2005 b.

Stanier, C. O., Khlystov, A. Y., and Pandis, S. N.: Ambient aerosol size distributions and number concentrations measured during the Pittsburgh Air Quality Study (PAQS), Atmos. Environ., 38, 3275-3284, ISI:000221838500015, 2004.

Stevens, B., Feingold, G., Cotton, W. R., and Walko, R. L.: Elements of the microphysical structure of numerically simulated nonprecipitating stratocumulus, J. Atmos. Sci., 53, 980-1006, ISI:A1996UD08500005, 1996.

Stier, P., Feichter, J., Kinne, S., Kloster, S., Vignati, E., Wilson, J., Ganzeveld, L., Tegen, I., Werner, M., Balkanski, Y., Schulz, M., Boucher, O., Minikin, A., and Petzold, A.: The aerosolclimate model ECHAM5-HAM, Atmos. Chem. Phys., 5, 11251156, ISI:000228059900001, 2005.

Strom, J., Okada, K., and Heintzenberg, J.: On the State of Mixing of Particles Due to Brownian Coagulation, J. Aerosol Sci., 23, 467-480, ISI:A1992JK55400006, 1992.

Subramanian, R., Khlystov, A. Y., and Robinson, A. L.: Effect of peak inert-mode temperature on elemental carbon measured us- ing thermal-optical analysis, Aerosol Sci. Tech., 40, 763-780, ISI:000239954300005, 2006.

Tegen, I. and Lacis, A. A.: Modeling of particle size distribution and its influence on the radiative properties of mineral dust aerosol, J. Geophys. Res.-Atmos., 101, 19237-19244, ISI:A1996VE25800026, 1996.

Twomey, S.: Pollution and the Planetary Albedo, Atmos. Environ., 8, 1251-1256, 1974.

Tzivion, S., Feingold, G., and Levin, Z.: The evolution of raindrop spectra. Part II: Collisional collection/breakup and evaporation in a rainshaft, J. Atmos. Sci., 46, 3312-3327, 1989.

Tzivion, S., Fiengold, G., and Levin, Z.: An Efficient Numerical Solution to the Stochastic Collection Equation, J. Atmos. Sci., 44, 3139-3149, 1987.

Van Dingenen, R., Raes, F., Putaud, J. P., Baltensperger, U., Charron, A., Facchini, M. C., Decesari, S., Fuzzi, S., Gehrig, R., Hansson, H. C., Harrison, R. M., Huglin, C., Jones, A. M., Laj, P., Lorbeer, G., Maenhaut, W., Palmgren, F., Querol, X., Rodriguez, S., Schneider, J., ten Brink, H., Tunved, P., Torseth, K., Wehner, B., Weingartner, E., Wiedensohler, A., and Wahlin, P.: A European aerosol phenomenology-1: physical characteristics of particulate matter at kerbside, urban, rural and background sites in Europe, Atmos. Environ., 38, 2561-2577, ISI:000221265500011, 2004.

Vignati, E., Wilson, J., and Stier, P.: M7: An efficient size-resolved aerosol microphysics module for large-scale aerosol transport models, J. Geophys. Res. Atmos., 109, ISI:000225400100001, 2004.

Volkamer, R., Jimenez, J. L., San Martini, F., Dzepina, K., Zhang, Q., Salcedo, D., Molina, L. T., Worsnop, D. R., and Molina, M. J.: Secondary organic aerosol formation from anthropogenic air pollution: Rapid and higher than expected, Geophys. Res. Lett., 33, ISI:000240642100006, 2006.

Weingartner, E., Burtscher, H., and Baltensperger, U.: Hygroscopic properties of carbon and diesel soot particles, Atmos. Environ., 31, 2311-2327, ISI:A1997XE53100014, 1997.

Wesely, M. L. and Hicks, B. B.: Some Factors That Affect Deposition Rates of Sulfur-Dioxide and Similar Gases on Vegetation, J. Air Waste Ma., 27, 1110-1116, ISI:A1977EA08300011, 1977.

Wexler, A. S., Lurmann, F. W., and Seinfeld, J. H.: Modeling Urban and Regional Aerosols .1. Model Development, Atmos. Environ., 28, 531-546, ISI:A1994NR21300012, 1994.

Wilson, J., Cuvelier, C., and Raes, F.: A modeling study of global mixed aerosol fields, J. Geophys. Res.-Atmos., 106, $34081-$ 34 108, ISI:000173879800053, 2001.

Yu, L. E., Shulman, M. L., Kopperud, R., and Hildemann, L. M.: Fine organic aerosols collected in a humid, rural location (Great Smoky Mountains, Tennessee, USA): Chemical and temporal characteristics, Atmos. Environ., 39, 6037-6050, ISI:000232762600003, 2005.

Yu, S. C., Kasibhatla, P. S., Wright, D. L., Schwartz, S. E., McGraw, R., and Deng, A. J.: Moment-based simulation of microphysical properties of sulfate aerosols in the eastern United States: Model description, evaluation, and regional analysis, J. Geophys. Res.Atmos., 108, ISI:000183746000002, 2003.

Zhang, Q., Worsnop, D. R., Canagaratna, M. R., and Jimenez, J. L.: Hydrocarbon-like and oxygenated organic aerosols in Pittsburgh: insights into sources and processes of organic aerosols, Atmos. Chem. Phys., 5, 3289-3311, 2005, 
http://www.atmos-chem-phys.net/5/3289/2005/.

Zhang, Y., Easter, R. C., Ghan, S. J., and Abdul-Razzak, H.: Impact of aerosol size representation on modeling aerosol-cloud interactions, J. Geophys. Res.-Atmos., 107, ISI:000180860300010, 2002.

Zhang, Y., Seigneur, C., Seinfeld, J. H., Jacobson, M. Z., and Binkowski, F. S.: Simulation of aerosol dynamics: A comparative review of algorithms used in air quality models, Aerosol Sci. Tech., 31, 487-514, ISI:000083886600008, 1999.

Zuberi, B., Johnson, K. S., Aleks, G. K., Molina, L. T., and Laskin, A.: Hydrophilic properties of aged soot, Geophys. Res. Lett., 32, ISI:000226510800003, 2005. 